\title{
Precariousness, Youth and Political Participation The Emergence of a new Political Cleavage
}

\author{
Monticelli, Lara; Bassoli, Matteo
}

Document Version

Accepted author manuscript

Published in:

Rivista Italiana di Scienza Politica

DOI:

10.1017/ipo.2018.11

Publication date:

2019

\section{License \\ CC BY-NC-ND}

Citation for published version (APA):

Monticelli, L., \& Bassoli, M. (2019). Precariousness, Youth and Political Participation: The Emergence of a new

Political Cleavage. Rivista Italiana di Scienza Politica, 49(1), 99-113. https://doi.org/10.1017/ipo.2018.11

Link to publication in CBS Research Portal

\section{General rights}

Copyright and moral rights for the publications made accessible in the public portal are retained by the authors and/or other copyright owners and it is a condition of accessing publications that users recognise and abide by the legal requirements associated with these rights.

Take down policy

If you believe that this document breaches copyright please contact us (research.lib@cbs.dk) providing details, and we will remove access to the work immediately and investigate your claim. 


\title{
Precariousness, Youth and Political Participation: The Emergence of a new Political Cleavage
}

Lara Monticelli and Matteo Bassoli

\author{
Journal article (Accepted manuscript*)
}

\section{Please cite this article as:}

Monticelli, L., \& Bassoli, M. (2019). Precariousness, Youth and Political Participation: The Emergence of a new Political Cleavage. Rivista Italiana di Scienza Politica, 491), 99-113. 00I: 10.1017/ipo.2018.11

This article has been published in a revised form in Rivista Italiana di Scienza Politica http://dx.doi.org/10.1017/ipo.2018.11

This version is published under a Creative Commons CC-BY-NC-ND. No commercial re-distribution or re-use allowed. Derivative works cannot be distributed. ㄷ Società Italiana di Scienza Politica २०1८

* This version of the article has been accepted for publication and undergone full peer review but has not been through the copyediting, typesetting, pagination and proofreading process, which may lead to differences between this version and the publisher's final version AKA Version of Record. 


\title{
Precariousness, Youth and Political Participation: The Emergence of a new Political Cleavage
}

\author{
By Lara Monticelli and Matteo Bassoli
}

\begin{abstract}
The article aims at disentangling the existing relation between job precariousness and political participation at the individual level illustrating that the former can be considered an emerging political cleavage. The authors apply an interpretive framework typical of political participation studies to an original data set composed of two groups of young workers (with precarious and open-ended contracts) in a big Italian post-industrial city, Turin. First, applying a confirmatory factor analysis, a typology of three 'modes' of political participation - voting, collective action, and political consumerism - is used to reduce data complexity. Second, logistic regressions are deployed to analyze the role played by occupational status, political positioning, and the interaction between the two, on the different modes of political participation. Precarious youth show a higher level of political participation in representational behaviours (voting). Left-wing youth are generally more active than non-left-wing ones in non-representational behaviours (collective actions and consumerism), the impact is more pronounced for precarious young people. Thus, results demonstrate the relevance of occupational status in explaining patterns of participation and invite scholars to promote a dialogue between industrial relations and political participation studies.
\end{abstract}




\section{Introduction}

The current state of the labour market in Europe is an issue of great concern in public debate. The media have been discussing the growing presence of precarious working conditions while scholarly studies have examined the rise of segmented labour markets. Labour-related protests and mobilizations have also received considerable attention. The Indignados and Mileuristas in Spain, and Movimenti Precari in Italy are among the most well known Southern European examples (Castañeda 2012; Lima and Artiles 2013; Murgia and Armano 2012), but similar movements are spreading all across Europe (Lahusen 2013). The rise of the 'gig economy' and digital labour platforms suggests that these trends are likely to continue into the near future (Malin and Chandler 2016; Milkman and Ott 2014; Harvey et al. 2016; Webster 2016). Nonetheless, the overwhelming attention given to collective mobilizations that seek to tackle precariousness and related issues such as austerity and cuts to benefits risks overlooking how individual workers are participating.

This article examines the effect of job precariousness on different forms of political participation among young precarious workers vis-à-vis regularly employed ones. In doing so, it seeks to identify and explain patterns and traits in how young people engage with and within the political arena. The well-known nexus between individual socio-demographic characteristics and political participation is taken into account by including all relevant socio-demographic characteristics and individual variables such as economic resources, time availability, civic skills (Brady et al. 1995), household burden (Coffé and Bolzendahl 2010; Marien et al. 2010; Schlozman et al. 1994; 1999) and social capital (La Due Lake and Huckfeldt 1998; McFarland and Thomas 2006; Putnam 2000; Van Der Meer and Van Ingen 2009).

Geographically, the article focuses on people living in the city of Turin (Italy). This city is located in the Piedmont region, which was once the heartland of Italian manufacturing. However, since the 1980s it has been subject to a large and continuous process of de-industrialization increasing precarious working conditions in the labour market (Monticelli and Bassoli 2016; Bassoli and Monticelli 2017). The survey is based upon an original sample of people between 18 and 34-yearsof-age, divided into two major groups: temporary workers and permanently employed workers. The 
survey includes both institutional and non-institutional types of political behaviour (Tarrow 2013; Stolle and Hooghe 2011).

The article is organized as follows: the first section presents the theoretical framework, emphasising the crucial interplay between individual variables - socio-economic characteristics, social capital and occupational status - with the local context; the second section presents the dataset and the methods and explains how factor analysis was used to identify youth-specific forms of participation; in the third section, hypotheses are tested through a set of logit regressions that show the decreasing relevance of the socio-economic status model (among youth) and confirm some wellknown hypotheses in the literature about political participation (the role of social capital and political interest); the final part of the article outlines the main empirical findings and discusses the potential of bridging political participation studies with sociology of work and industrial relations.

\section{Occupational Status and Political Involvement: The State of the Art}

Most people would agree that a properly functioning democracy requires citizens to actively participate in the political arena. They should have the opportunity to engage in the political system through the typical range of tools provided by representative democracies. Two of the most important tools are voting and involvement in party politics. But when it comes to challenging the status quo, citizens have historically deployed a different repertoire of actions, ranging from protests to violent actions and, more recently, shifting their focus from the State to markets with individual or collective forms of political consumerism aimed at positively or negatively discriminating between products for ethical, environmental and political reasons (Micheletti 2003; Forno and Graziano 2014).

Nonetheless, one of the most striking and enduring findings in the field of political participation studies is the unequal distribution, across the population, of the propensity towards political activism (Stolle and Hooghe 2011). Among the factors influencing these discrepancies identified by the traditional literature on political participation, we find economic resources, age, educational attainment, social capital, familial background and occupational status (Brady et al. 1995; Coffé and Bolzendahl 2010; La Due Lake and Huckfeldt 1998; Lorenzini and Giugni 2012; Marien et al. 2010; 
McFarland and Thomas 2006; Schlozman et al. 1994; 1999; Van Der Meer and Van Ingen 2009; Solt 2008).

More specifically, two broad strands of literature have tackled the relationship between employment and political participation. On the one hand are scholars who consider unemployment as a trigger for collective action and increased interest in socio-political issues (Demazière and Pignoni 1998; Gamson 1968; Wilkes 2004; Maurer and Mayer 2001; Stolle and Hooghe 2011, Piven and Cloward 1977). On the other hand, there are scholars who describe unemployment as a hindering factor for political activism (Brady et al. 1995; Schlozman et al. 1999; Verba et al. 1978; 1993). The first strand, often referred to as the 'grievance model' (Kern et al. 2015), often considers any sort of resentment, once it is translated explicitly into political demands, as representing a strong incentive for political activism at the individual level (Gamson 1968; Gurr 2011; Wilkes 2004; Stolle and Hooghe 2011). Similarly, others interpret unemployment as a boost for collective action and mobilization (Baglioni et al. 2008; Demazière and Pignoni 1998; Maurer and Mayer 2001; Piven and Cloward 1977). In other words, political participation is considered a viable way for marginalized social classes to escape from social isolation, express their discontent, make political claims and fight the social stigma attached to unemployment.

As for the second strand of literature, often referred to as the civic voluntarism model (Verba et al. 1993), scholars have demonstrated that political participation is supported and fostered by the availability of individual resources: money, time, civic skills and social capital (Brady et al. 1995; Schlozman et al. 1999; Verba et al. 1978; 1993). Research on the impact of labour conditions has consistently shown that unemployed people tend to be less politically active than regular workers (Anderson 2001; Brady et al. 1995; Coffé and Bolzendahl 2010; Driskell et al. 2008; Schlozman et al. 1999; Van Der Meer and Van Ingen 2009). 


\section{Job Precariousness: The Missing Piece of the Puzzle}

A rich body of literature has been produced in last decade with the goal of shedding light on the nuanced concept of precariousness. Scholars within the field of sociology of work believe that precariousness can be better defined by looking at the context and at the consequences of job conditions in terms of citizenship rights and social guarantees rather than by focusing on the type of contract (Mattoni and Vogiatzoglou 2014; Murgia and Armano 2012). In fact, temporary contracts' conditions and related social guarantees may vary consistently across and within European countries, pointing out the necessity of going beyond mere contractual features to assess job-related degree of precariousness. In other words, workers with open-ended contracts might experience precariousness as much as, if not more than, workers with temporary contracts. In spite, and probably exactly because of this complexity, it is difficult to find a ready-made definition of precariousness in the literature.

Rather than a static condition, precariousness is often referred to as a multi-dimensional, complex process shaped by the dynamics of contemporary capitalism, the actions (and re-actions) of the people involved and the institutional mediation between the two (della Porta et al. 2016). As stated above, precariousness is not - or not only - the consequence of the contractual status, but it constitutes also a subjectively perceived condition. Given its broad scope, the concept of precariousness has been deployed to describe workers in disparate sectors ranging from university to the sharing and gig economy. As stated in a recent publication 'the precariat remains a contestable and polyvalent term, giving rise to and reason for endless definitional debates and classificatory clashes' (Silvasti and Hänninen, 2016: 159).

Returning to the role of occupational status in triggering political participation and, in particular, collective mobilizations, precariousness has been rarely analyzed within the framework of the grievance model. Classical studies on the diffusion of unemployed people's collective movements (Maurer and Mayer 2001; Piven and Cloward 1977) overshadow other occupational conditions, not to mention the difficulties that precarious youth face in self-organizing (Mattoni 2016) and accessing existing trade unions (Alberti et al. 2013; Keune 2015). 
More recent studies on precarious collective movements in Europe point toward the emergence of some kind of group-consciousness (Mattoni and Doerr 2007) even though this dynamic is difficult to assess given the simultaneous presence and the interplay with anti-austerity movements. Only few studies examine the political attitudes and voting preferences of precarious workers based on single or cross-national case studies (Bay and Blekesaune 2002; Corbetta and Colloca 2013).

As regards the civic voluntarism model, occupational status is usually treated as an unproblematic individual variable (Anderson 2001; Brady et al. 1995; Coffé and Bolzendahl 2010; Driskell et al. 2008; Schlozman et al. 1999; Schur 2003; Van Der Meer and Van Ingen 2009).

Broadly speaking, the literature has dealt with the issue of occupational status and political participation by drawing a sharp distinction between full-time employment and unemployment, without identifying 'intermediate' situations (such as part-time jobs, self-employment or fixed-term contracts) or without differentiating between workers' individual characteristics. Indeed, employment for a young person today has a different meaning and significance compared to an older person, just as having a job has a differential effect on the individual life trajectory of a man or a woman (Schlozman et al. 1999). Analogously, part-time or temporary jobs might have different impacts on the repertoire of political actions compared to permanent full-time employment, as is the case for political attitudes (Corbetta and Colloca 2013; Eichhorst and Marx 2015; Marx 2014; Marx and Picot 2013).

In light of this, this article aims at tackling the following research questions: Are precarious workers more prone to political activism than their counterparts holding open-ended jobs? Do they tend to choose representative channels of political participation or do they prefer to engage directly in grassroots and contentious political actions?

To begin answering these questions one should contextualize precariousness in the Italian case. 


\section{The Italian Socio-Economic and Political Context}

The labour market of temporary jobs in Italy is two-tiered, with a primary segment offering well-paid job positions and a secondary segment offering short-term, low-paid work with no career and stabilization prospects. Therefore, temporary positions may be used as probationary periods serving as 'stepping stones' towards more rewarding positions (Scherer 2001, 2004), while others such as seasonal or casual jobs - are de facto potential traps that promise dead-end precarious careers (Bruno et al. 2014; Picchio 2012; Pavlopoulos 2013). Moreover, a strong internal divide exists between precariously employed young people holding a university degree and those who do not (Barbieri 2011; Lodovici and Semenza 2012). Scholars hypothesize that tertiary-educated young people tend to have more stable and better remunerated job trajectories than those who are less educated, since they possess a relatively higher bargaining and signalling power than their lower educated peers (Gebel and Giesecke 2011). This dynamic is quite common across Southern European countries. What is more specific to each country is the impact of job precariousness on political participation patterns.

The political attitudes of Italian citizens have been widely studied in comparative terms. Italy often appears as an outlier, together with Portugal and Spain. Undoubtedly, welfare regimes, institutional incentives and cultural characteristics do affect social inclusion and specific forms of political participation (Bassoli and Monticelli 2016). According to the existent literature, four aspects are unique to the Italian context.

Firstly, Bay and Blekesaune (2002) showed that Italy is the only country in the EU where unemployed young people trust the democratic system more than their employed counterpart. However, the overall level of satisfaction among Italian young people is impressively low: 'political distrust is a majority attitude in Italy. [...]. Bluntly stated, it can be maintained that it is those who are satisfied who form the deviant group in Italy' (Bay and Blekesaune 2002: 138). Secondly, extreme political positions on the left-right scale persist among Italian young people, who are also significantly influenced by the political positioning of their parents and relatives (Ogris and Westphal 2005). Thirdly, there is a general agreement about the salience of the precariousness issue. 'The 
traditional "lenses" focusing on the insiders/outsiders divide are inadequate to grasp the ongoing changes in the Italian labour market: at least a third category of workers, the 'mid-siders' (Jessoula et al. 2010:561-562), - or precarious, is needed. Fourth, Italy is characterized by deeply rooted political subcultures. A political subculture is composed of a group of people that fit into the larger culture, but have specific political beliefs that set them apart from the larger group to varying degrees. This means that while they may share some ideas and objectives with the dominant group (such as trust in representative democracy), they oppose the status quo, hoping to change certain aspects of the system to align it with their beliefs. This is specifically true for Italy.

Since the end of WWII, Italians strongly identified either in the Communist Party (PCI - Partito Comunista Italiano), in the Christian Democratic Party (DC - Democrazia Cristiana) or in the postFascist Party (MSI - Movimento Sociale Italiano). The first two parties were either in the majority or in the minority depending on the geographic area considered. The affiliation to a specific political subculture boosted political participation in various ways among different groups of the population (Corbetta and Colloca 2013). Indeed, regional and local political subcultures seem to still help predict the behaviour of civil society organisations (Bassoli 2017) and that of the general population (Bassoli et al. 2011; Monticelli et al. 2016; Diamanti 2009).

Concerning the role played by occupational status in fostering political participation, Baglioni, della Porta and Graziano (2008: 846) show that, at least in Italy, unemployment translates into claims-making under two conditions: the presence of political entrepreneurs and their visibility in the public sphere. The activation of precarious youth might depend on similar conditions. Precariousness, in fact, represents nowadays an oft-invoked discursive framework in the media and in the political debate (Doerr et al. 2015). Focusing on Italian precarious workers' political attitudes, Corbetta and Colloca (2013) found that precarious workers are different from their counterparts holding open-ended contracts or being unemployed: 'They did not share with unemployed people this feeling of political disillusion; in addition, they appeared ideologically to be the most leftist group (slightly more leftist than regular workers)' (Corbetta and Colloca 2013: 16). 
Findings for other continental countries are similar to a certain extent (Eichhorst and Marx 2015; Emmenegger et al. 2015; Marx 2014). Marx and Picot (2013) show that a growing number of atypical workers in Germany exhibit a propensity to vote for New Left and Green parties rather than traditional Social-Democratic ones - the former being much better at representing these voters' preferences for redistributive policies and claims against the status-quo. However, to the best of our knowledge, no empirical evidence exists on the range of political actions performed by precarious individuals other than their voting preferences.

As briefly described in a previous article (Bassoli and Monticelli 2017), all the above mentioned strands of research suggest that, in Italy, some systemic variables are creating the preconditions for a new political cleavage to emerge along the dimension of job precariousness. If one accepts the definition of political cleavage as linking 'the social reality of openness/closure of individual life chances to the likelihood of collective and organized action through the mediation of socially shared systems of beliefs' (Kriesi 2010: 674), it appears clear how the impossibility to exit a condition of precariousness might trigger certain forms of political participation. The overarching theoretical background of this article is that, given the characteristics of contemporary capitalism and its consequences on labour market structures, precariousness might constitute an emerging political cleavage, especially amongst the most affected groups, including young people. In the following section, the main research hypotheses are described along with the main variables used in the analysis.

\section{Conceptual Framework and Research Hypotheses}

Many individual variables must be controlled for in order to test the relative impact of occupational status. We therefore use a conceptual framework built using insights from three strands of political participation studies. We build on the idea that political participation may be explained by individual characteristics (gender, age and education - the so called socio-economic status, SES model) and economic resources (the availability of time and civic skills) (Brady et al. 1995). 
The first layer, based upon the resource-based model, convincingly explains individual differences in political participation and departs from the SES model (age, class, education) while also considering other resources developed during an individual's lifetime, such as spare time, skills and income (Schlozman et al. 1994; 1999).

As a second theoretical pillar, the literature has stressed the importance of gender in helping to explain differential gaps in political activism between men and women. According to these studies (Coffé and Bolzendahl 2010; Marien et al. 2010; Lorenzini and Bassoli 2015), the registered political participation gap is not related to gender itself, but to the specific resources that women and men have at their disposal within the household. Therefore, in a country like Italy, with a weak welfare regime and a strong imbalance in the division of domestic responsibility between men and women, abstention from politics may be stronger for women who provide more household care than men.

Finally, scholars have also stressed the importance of social capital. They distinguish between structural social capital created by actual networks of friendship and acquaintances (La Due Lake and Huckfeldt 1998) and civic engagement created through participation in voluntary associations, either in the past (McFarland and Thomas 2006) or in the present (Eggert and Giugni 2010; Stolle et al. 2005; Van Der Meer and Van Ingen 2009). ${ }^{1}$ Both conceptualisations consider social capital to have a positive impact on all forms of participation and are therefore included as part of the model.

As regards the role played by the political, institutional and geographical context, it is important to consider the existing polarization of the Italian political arena (Pizzorno 1966), as the left-right positioning can explain certain political activism (Van Der Meer et al. 2009). Given the specificity of political subculture in the city of Turin, the left-wing youth in Turin should be more active than their right-wing counterpart because they are 'more central' relative to the city's leftist political and social tradition (Diamanti 2009). More extreme positions (on the extreme left or extreme right of the political spectrum) are expected to trigger more contentious forms of political behaviour (Van Der Meer et al. 2009). From this, we derive the following hypotheses: 
Hp 1.1 : Young individuals with extreme political positions are more likely to engage in more contentious forms of political participation (strikes, blockades, etc.) than their moderate counterparts;

Hp 1.2 : Leftist young individuals of Turin are more likely to engage in all forms of political participation than their right-wing counterparts.

Concerning occupational status, as described in Section 2, two competing hypotheses have been debated among scholars. According to many studies in this area, and coherent with the social marginalisation strand (Brady et al. 1995), the unemployed should be less engaged in all forms of participation, while precariously employed youth should behave similarly to the 'fully' employed youth (Polavieja 1999; Schur 2003). As mentioned earlier, the reason for this can be traced back to the role of social stigma. Unemployed people may feel that a stigma is attached to them which produces marginalisation and isolation in the contemporary context (Monticelli et al. 2016) just as they did in the nineteen thirties (Lazarsfeld et al. 1981). This phenomenon affects the political dimension.

However, considering the contentious politics of unemployment and precariousness in Italy (Baglioni et al. 2008) and the fact that precarious workers and unemployed people are often found to be less stigmatized in Italy than in other countries (Murgia and Armano 2012; Bay and Blekesaune 2002), we expect that the level of political participation among precarious workers will actually be higher than their counterparts holding open-ended contracts (Hp. 2). This hypothesis must be controlled for by educational attainments because tertiary-educated young people tend to display more stable and better-remunerated job trajectories than less educated young people. At the same time, tertiary education is usually associated with higher levels of political participation. Thus the interaction between these two variables (education and precariousness) has to be assessed.

Hp 2 : Precarious workers are more likely to participate than workers with open-ended contracts. 
In testing these hypotheses, a control for the interaction between occupational status and political positioning is included, given the importance of local contextual political subcultures, especially the leftist one in the case of Turin.

\section{Beyond Voting: the Multifaceted Nature of Political Participation}

The dataset contains 949 individuals aged 18-34 who live in the city of Turin, interviewed using the $\mathrm{CATI}^{2}$ method between June 2009 and October 2010. This dataset is part of the EU-funded research project YOUNEX. ${ }^{3}$ The sample is equally divided into two groups of individuals temporary workers and a reference group comprising workers with open-ended contracts who have worked for the last 12 months in the same workplace.

Aware of the debate about precariousness and its subjective side (De Witte and Näswall 2003), but limited by the quantitative nature of the data available, we constructed the category of 'precarious workers' by deploying temporary contracts as a proxy (Corbetta and Colloca 2013; Eichhorst and Marx 2015; Marx 2014; Marx and Picot 2013). In the survey, the category of temporary workers was built through a series of 'filter' questions asked at the beginning of the interview. The resulting category includes a wide array of contracts: projects, on call, seasonal, self-employed with only one contractor, temporary and fixed-term. In order to test the reliability of temporary workers as a proxy of precarious workers, we ran a series of parametric and non-parametric statistical tests (Kendall's tau, Spearman's rho and Student's t-distribution) crossing the variable on the type of contract with other relevant variables within the dataset. We found that temporary workers display significantly lower levels of income and unionization than workers with open-ended contracts. The survey also shows how their main source of monthly income is not just dependent on their salary, but also on someone else salary. However, this fragility in income is similar to their permanently employed counterparts: descriptive statistics run on the dataset show that there is no statistical difference between the two groups in the perception of financial difficulty that living with their present income generates (see variable "financial difficulty" in Appendix 2 and 4). 
Turning to the impact of contextual variables, the impact of political subcultures was considered using leftist political stance while controlling for extreme political positioning. Political positioning is measured using a $0-10$ self-positioning scale, while extreme political positioning is a dichotomous variable coded as one for those placing themselves below one or above nine. This codification allows us to test hypotheses 1.1 and 1.2 simultaneously. With regard to the other independent variables, we deployed standard operationalizations (see Appendix 2).

Concerning the independent variables, we followed the approach developed by Verba et al. (1978: 51-56; 310-339) that involves the identification of patterns of coherent behaviours called 'modes of political participation'4 (ibidem). In this article we use a more recent typology developed by Teorell et al. (2007: 345) which identifies four modes: voting, party activity, collective action and consumer participation. The typology is built along two dimensions: channel of expression and mechanism of influence.

The first dimension, channel of expression, is broken down into two broad types: behaviours taking place within the framework of representative democracy and behaviours taking place through extra-representational channels of expression. For the second dimension, mechanism of influence, Teorell and colleagues rely on Hirschman's popular distinction between 'exit' and 'voice' as distinct political strategies (Hirschman 1970). More specifically, they identify two representational modes of political participation: 'voting' is the exit-based mode, while 'party activity', by contrast, is the voicebased mode. Voters, in fact, may change party once they are not satisfied (exit strategy), while party members can 'voice' their dissatisfaction in congresses and assemblies (voice strategy). The same dual structure can be applied to extra-representational forms of participation: the exit-based mode is political consumerism (i.e., the choice of boycotting or 'buycotting' specific products), while the voice-based mode is collective action. While political consumerism works according to market-like dynamics, collective action is based upon the flow of information towards (and often, against) political and institutional elites. 
Table 1 Modes of political participation

\begin{tabular}{|l|c|c|c|}
\hline \multicolumn{2}{|c|}{} & \multicolumn{2}{c|}{ Channel of Expression } \\
\cline { 2 - 4 } \multicolumn{2}{|c|}{} & Representational & Extra-Representational \\
\hline \multirow{2}{*}{ Mechanism of Influence } & Exit & Voting & Political Consumerism \\
\cline { 2 - 4 } & Voice & Party Activity & Protest, Collective Action \\
\hline
\end{tabular}

Source: adaptation from Teorell et al. (2007: 340)

Even though Teorell et al. (2007) illustrated quite robust results on thirteen European countries, Italy was not included in the sample. The typology was therefore tested on the sample under investigation using a confirmatory factor analysis based on the four items described above and imposing a varimax rotation given the orthogonal nature of the factors (Appendix 1). ${ }^{5}$ Teorell's typology was found to hold valid in the sample and similar labels were given to the factors: voting, party activity, consumer participation and collective action (see Appendix 1 for further details). In the following analysis, though, the factor 'party activity' was dropped from the analysis because all young people actively engaged in that form were precarious, making it impossible to conduct a comparative analysis (see Appendix 3).

Thereafter a set of logistic regressions was launched to test hypotheses $1.1,1.2$ and 2 . The baseline model (Appendix 4) assesses the impact of occupational status on different forms of participation that emerged from the factor analysis. ${ }^{6}$ The baseline model includes variables for gender, age, education, nationality, as well as economic resources, time availability, civic skills, familial burden, social capital and political resources (see Appendix 4 for further details). The baseline model was extended by adding and testing the effect on political participation of four different types of variables. The first model tests the role of extremism (Hp 1.1) by considering extreme political positioning only (Partial model A). The following model tests the importance of leftist political positioning on participation (Hp 1.2) by considering political positioning only (Partial model B). Finally, the third model is testing the two hypothesis simultaneously, leaving in the fourth 
model the interaction terms between political positioning and occupational status ( $\mathrm{Hp} 2)$. All models were tested running binary logistic regressions. Logistic regressions were chosen instead of ordinal logistic regressions since forms of participation - operationalized as ordinal scales - could not fit the mandatory proportional odds assumption (or parallel regression assumption).

In a second step of the analysis, we run some robustness checks: one concerning the role of extremism using a quadratic relationship with the political positioning (see Appendix 5) and the other on the role of education. The effect of precariousness at different educational levels was assessed using interaction terms allowing to control for the divide between low educated and highly educated flexible workers (Appendix 6).

The following section illustrates and discusses the results of the empirical analysis by presenting average marginal effects $(\mathrm{AME})^{7}$ and predictive margins at representative values to facilitate the interpretation of results.

\section{Engaged Precariat in Turin: Young, Educated and Left-Wing}

Table 2 presents an overview of the impact of political positioning on the different modes of political participation, controlling for the different sets of identified predictors with a specific focus on the complete models (models 1 and 2, Appendix 4). The first finding concerns the limited impact of extreme political positions: the variable is almost never significant, except for 'political consumerism'. Young people with an extreme political position are 11 per cent less likely to be active in this form of political participation vis-à-vis those declaring a more moderate position on the political scale. This finding does not support hypothesis 1.1, collective action (a typical extrarepresentational form of political participation) is not positively influenced by an extreme political positioning, probably because of the limited contentiousness of this form of political participation in the city of Turin. We also controlled for a quadratic relationship with the political positioning (see Appendix 5), but results are similar to those found by running the model with the variable "extreme political positioning", which was thus preferred given the lack of collinearity. 
Turning to hypothesis 1.2 , concerning the role of a left-wing political positioning on political participation, the findings lead to more nuanced conclusions than expected. While leftist youth were expected to be more active in all modes of political participation, this is not true for voting. In the full model without interaction (model 1 in Appendix 4), political positioning plays a role in both political consumerism and collective action: those with a right-wing political positioning participate less in both forms of political participation ( $-2.2 \%$ and $-3.2 \%$ respectively). The same trend (also in magnitude) holds valid when precarious workers and workers with open-ended contracts are analyzed separately, using interaction terms. The impact of political positioning is stronger on precarious young people compared to their permanently employed counterparts. For political consumerism, the impact of right-wing political positioning decreases the rate of political participation among regular workers by 1.9 per cent compared to 2.4 per cent for precarious workers. Whereas for collective action, the expected rate of political participation diminishes by 2.3 per cent for right-wing regular workers compared to -3.9 per cent for precarious young people with the same political positioning. Overall, political positioning seems to influence youth activation in extrarepresentational modes of political engagement, especially in the case of precarious youth. 
Table 2. Effect of precarious job condition in predicting non-institutionalised participation

\begin{tabular}{|c|c|c|c|c|c|c|}
\hline & $\begin{array}{c}(1) \\
\text { Voting }\end{array}$ & $\begin{array}{c}(2) \\
\text { Voting }\end{array}$ & $\begin{array}{c}(1) \\
\text { Consumeris } \\
\mathrm{m}\end{array}$ & $\begin{array}{c}(2) \\
\text { Consumer } \\
\text { ism } \\
\end{array}$ & $\begin{array}{c}\text { (1) } \\
\text { Collective } \\
\text { action }\end{array}$ & $\begin{array}{c}\text { (2) } \\
\text { Collectiv } \\
\text { e action }\end{array}$ \\
\hline $\begin{array}{l}\text { Extreme } \\
\text { political } \\
\text { positioning }\end{array}$ & 0.019 & & $-0.111^{* *}$ & & 0.028 & \\
\hline $\begin{array}{l}\text { Left-right } \\
\text { political } \\
\text { positioning }\end{array}$ & 0.001 & & $-0.022^{* *}$ & & $-0.032^{* * *}$ & \\
\hline $\begin{array}{l}\text { Regular w. X } \\
\text { left- right } \\
\text { positioning }\end{array}$ & & -0.000 & & $-0.019^{*}$ & & $-0.023^{* *}$ \\
\hline $\begin{array}{l}\text { Precarious X } \\
\text { left- right } \\
\text { positioning }\end{array}$ & & 0.003 & & $-0.024^{* *}$ & & $-0.039^{* * *}$ \\
\hline $\begin{array}{l}N \\
\text { nseudo } R^{2}\end{array}$ & $\begin{array}{c}564 \\
0133\end{array}$ & $\begin{array}{c}564 \\
0134\end{array}$ & $\begin{array}{c}612 \\
0141\end{array}$ & 612 & $\begin{array}{l}615 \\
0187\end{array}$ & $\begin{array}{c}615 \\
0190\end{array}$ \\
\hline
\end{tabular}

We present AME calculated when moving from fully employment to precarious job condition. Model 1 - Controls included: gender, age, citizenship, educational level, financial situation, children, associational involvement, political interest, internal political efficacy and political knowledge

Model 2 - Controls included: model 1 and interaction term between employment status and political self-positioning

Source: Annex 4, model 1 to 2, for each dependent variable ${ }^{*} p<0.05,{ }^{* *} p<0.01,{ }^{* * *} p<0.001$

These findings do not mean that right-wing precarious youth are the least active group. The interaction term, presented in Table 2, assesses the impact of political positioning on precariousness, not the rate of participation in absolute terms. In order to better understand the role of a left-wing political positioning on the Turinese precariat, we deploy figures to highlight the patterns and the rates of political engagement. Considering model 2, the following figures illustrate the predicted probabilities of participating in different forms of political activities (voting, consumerism and collective action) by employment status for different political positioning.

In Figure 1, the flat line, comprising regular workers, suggests that the probability of participating (around 89 per cent) is not depending on political positioning. At the same time, the upper line, positively inclined from left to right, depicts the predicted probabilities of voting for precarious young people. It also highlights that the previous positive effects of being precarious on 
the probability of voting (between 6 and 9 per cent) is now statistically non-significant. The loss of explanatory power is represented by the lack of distance between the two lines. In model 2, the effect is thus 'absorbed' by the interaction term, showing that precarious workers are similar to their counterparts with open-ended contracts once political positioning in taken into consideration. Moreover, the importance of declaring a left-wing political positioning (hypothesis 1.2) does not hold when the effect of job precariousness is taken into consideration. 


\section{Figure 1. Predicted probabilities of voting by political self-positioning}

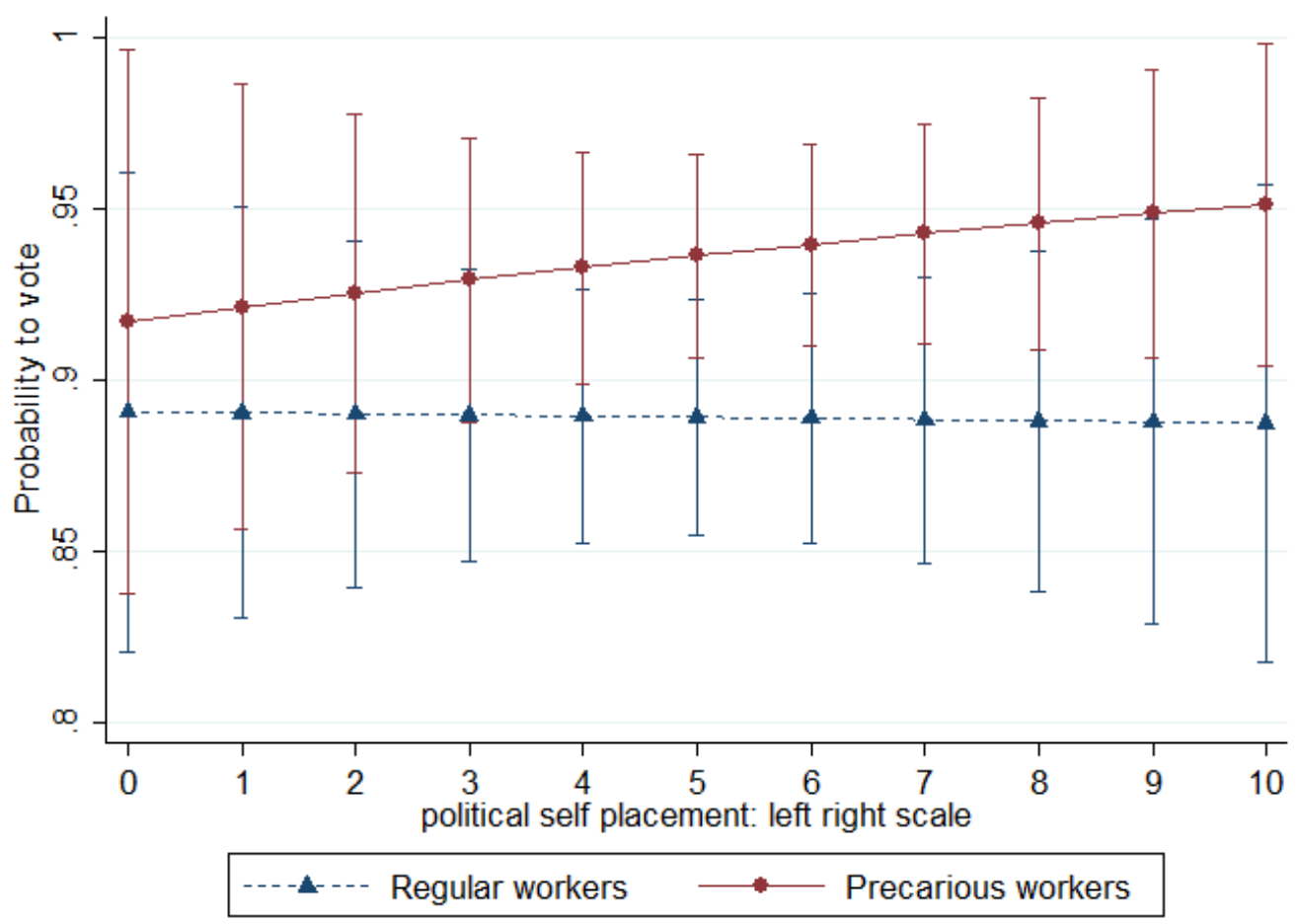

Source: AME are calculated based on annex 4, Model 2 (with all controls and interaction terms)

Focusing on non-representational modes of participation, the results reveal a slightly different picture. Looking at Figures 2 and 3, it is clear that precarious youth and regular workers show similar patterns, strongly influenced by political positioning. The two lines present similar decreasing trends as one moves from left-wing to right-wing political positions. In both job conditions, predicted probabilities are influenced by political positioning. Left-wing young people show higher chances of engaging in political consumerism compared to right-wing young people. At the extremes, the difference reaches 20 per cent for consumerism and 40 per cent for collective action. However, the interaction term between political positioning and occupational status is not significant since the difference between the two groups is not affected by political positioning, i.e. the distance between the two lines is not statistically affected. 
Figure 2. Predicted probabilities of engaging in consumerism by political self-positioning

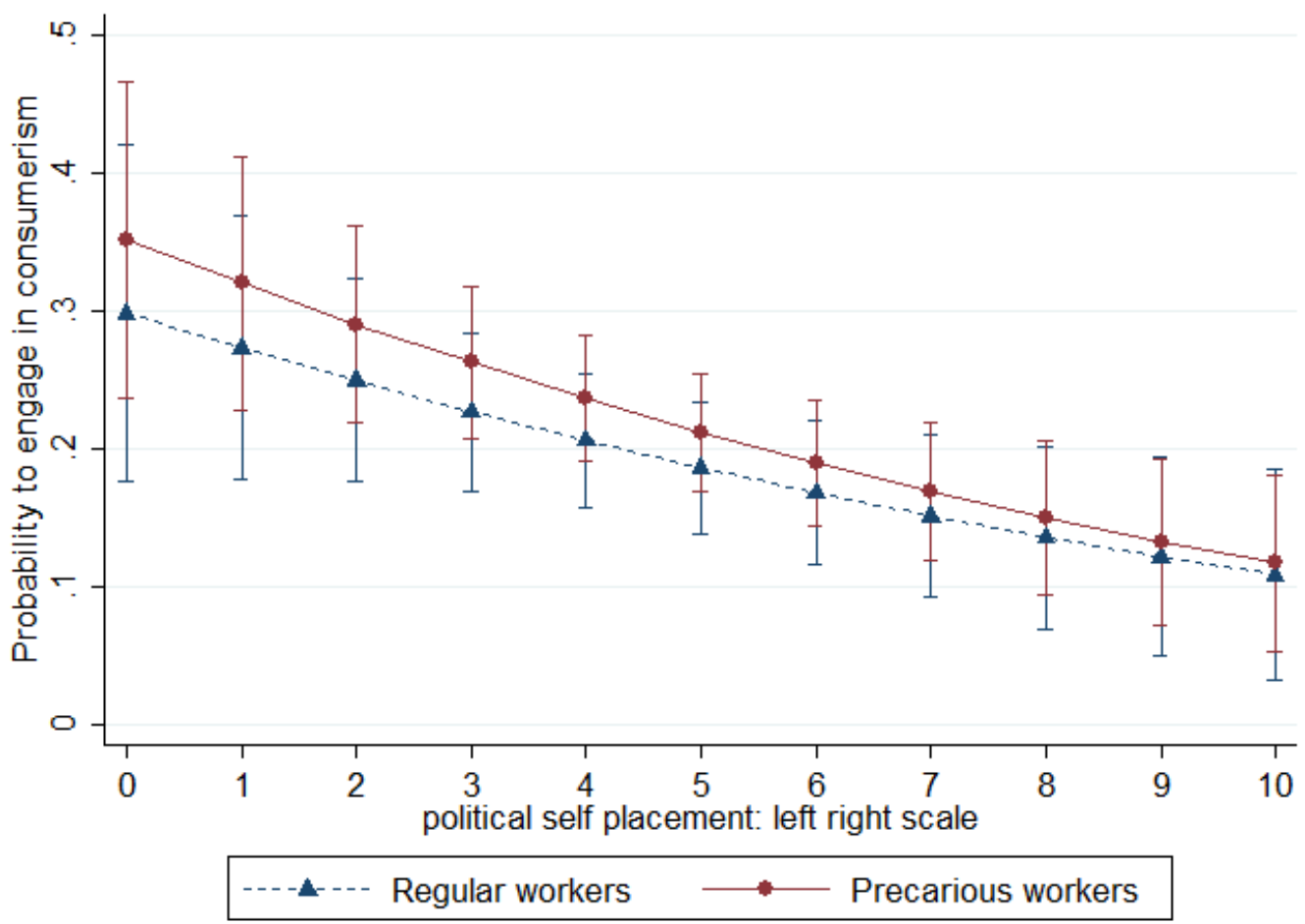

Source: AME are calculated based on annex 4, Model 2 (with all controls and interaction terms)

Figure 3. Predicted probabilities of engaging in collective action by political self-positioning

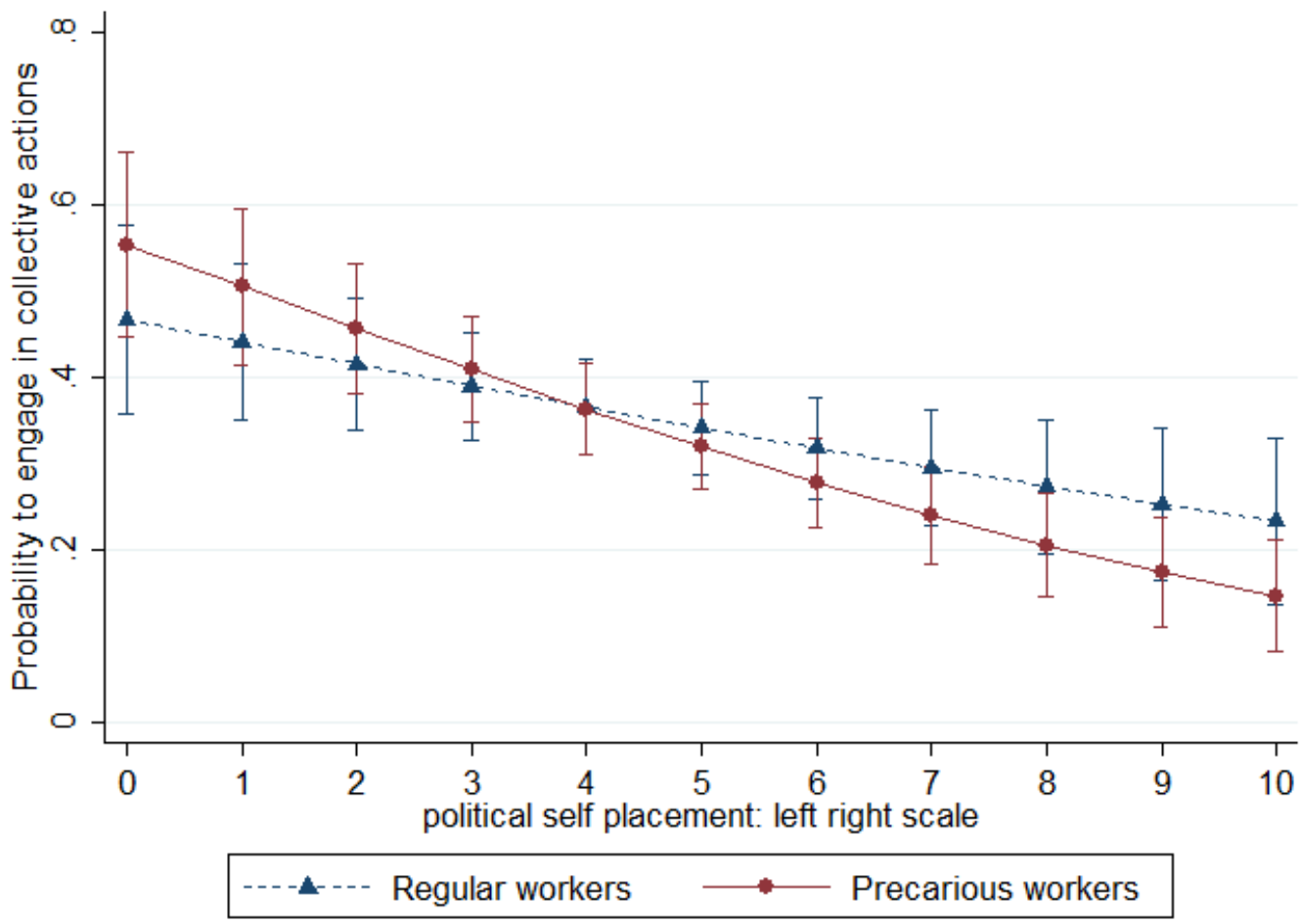

AME are calculated based on annex 4, Model 2 (with all controls and interaction terms) 
To conclude, the role of education was specifically analyzed because - according to the literature presented above - it is usually considered a strong predictor of political participation. Moreover, since some scholars suggest that educational levels might play a major role in the process of occupational stabilization or 'precarisation' of career trajectories, a specific control for the mediator effect of education was introduced in the analysis. Results show that educational attainment is not a particularly strong predictor of political participation (Appendix 4). On the other hand, the interaction with job condition is rarely significant. More precisely, in the main model there is no evidence of educational attainment influencing the probability of voting and enacting consumerism, nor a moderating effect while considering the interaction term (Appendix 6). In sum, tertiary education only positively influences the level of mobilization in collective action (Appendix 4) for both precarious and permanently employed youth (Appendix 6).

\section{Job Precariousness: An Emerging Political Cleavage}

The aim of this article is to disentangle the relationship between occupational status and political participation by analysing a sample of young Italian workers and their patterns of individual and collective political engagement. While the extant literature has demonstrated an increasing interest in the preconditions that foster or hinder political participation, this article demonstrates the fruitfulness of adopting an approach that considers the interplay between job precariousness and the range of actions that individuals engage in, both inside and outside the political arena of representative democracy. In the case of Turin, this article shows how precariousness affects the political participation of young people, while also drawing attention to the importance of political positioning and political subcultures.

In short, the findings suggest that precarious young workers tend to participate more in representational forms of political participation (voting) than their counterparts with open-ended contracts. On the other hand, precarious workers do not show any difference when focusing on nonrepresentational forms of political participation: political consumerism and collective action. Another finding concerns the role played by the interaction between occupational status and left- 
wing political positioning. While a left-wing political positioning is connected to a higher level of non-representational political activity, the impact is more pronounced for precarious young people than for permanent contract workers.

In addition, left-wing young people participate more in two forms of political participation due to an interaction between political positioning and occupational status rather than the left-wing subculture of Turin. While a leftist political positioning is often a trigger for high levels of political participation among young people, when it interacts with occupational status, the triggering effect is present for both regular and precarious workers. This sheds lights on the hypothesis put forward at the beginning of the article, i.e. the centrality in Turin is not only a matter of leftist political position, but also a matter of more nuanced characteristics at the individual level such as the level of educational attainment, civic skills and occupational status.

To conclude, the article suggests, as highlighted by recent research (Bassoli and Monticelli 2017), that an insecure occupational status does constitute a contemporary political cleavage able to trigger the political activation of precarious workers both at the individual and collective level (Kriesi et al. 2006; Kriesi 2010). In other words, the distinction between precarious workers and workers with open-ended contracts is relevant and should be carefully considered when analysing individual employment trajectories as well as patterns of civic, political and social engagement. More broadly, this article demonstrates how the debate on the struggles of precarious workers in the sociology of work and industrial relations could benefit from a deeper dialogue with interpretive frameworks typical of social movement and political participation studies.

\section{Endnotes:}

1) Obviously, different kinds of associations play different roles: for migrants, inter-ethnic organisations are more relevant for political participation (Eggert and Giugni 2010); in labour studies, trade unionism plays a central role (Schur 2003). Among the other types of associations, 'activist associations' are the best predictor of political engagement (Van Der 
Meer \& Van Ingen 2009); and 'distant organisations' are stronger predictors than 'face-toface' organisations (Stolle, Hooghe \& Micheletti 2005).

2) Computer Assisted Telephone Interview.

3) Additional information can be found on the project website anonymized. Data are meant to be public so they can be obtained upon request.

4) The four modes are: voting, campaign activity, communal activity and particularized contacting.

5) An oblique rotation produced analogous results.

6) Occupational status is a categorical variable coded as zero for those unemployed more than 12 months, one for those holding a fixed-term contract, and two for those who are employed with a permanent position.

7) AME calculates the effect on political engagement of shifting from unemployment to regular job or from regular job to precarious work, from non-extreme political positioning to extreme political positioning, from left-wing to right-wing youth, holding all other variables at their observed values.

\section{Funding Note}

The research has been funded by European Commission under the 7th Framework Programme (Grant Agreement No. 216122).

\section{Note on Replication Material}

The replication dataset is available at http://thedata.harvard.edu/dvn/dv/ipsr-risp

\section{Acknowledgments}

Results presented in this article have been obtained within the project "Youth, Unemployment, and Exclusion in Europe: A Multidimensional Approach to Understanding the Conditions and Prospects for Social and Political Integration of Young Unemployed' (YOUNEX). The authors wish to thank 
all the members of the research consortium and, in particular, the other members of the Italian research team, Simone Baglioni and Paolo R. Graziano. The authors are also grateful to the two anonymous reviewers for their comments that helped improving the initial draft of this article. The authors declare that they have no conflict of interest.

\section{References}

Alberti, G., Holgate, J., \& Tapia, M. (2013). Organising migrants as workers or as migrant workers? Intersectionality, trade unions and precarious work. The International Journal of Human Resource Management, 24(22), 4132-4148. https://doi.org/10.1080/09585192.2013.845429

Anderson, C. J. (2001). Desperate Times Call for Desperate Measures? In N. Bermeo (Ed.), Unemployment in the New Europe (pp. 271-290). Cambridge: Cambridge University Press.

Baglioni, S., Baumgarten, B., Chabanet, D., \& Lahusen, C. (2008). Transcending marginalization : the mobilization of the unemployed in France, Germany, and Italy in a comparative perspective. Mobilization, 13(3), 323-335.

Baglioni, S., della Porta, D., \& Graziano, P. (2008). The contentious politics of unemployment: The Italian case in comparative perspective. European Journal of Political Research, 47(6), 827-851. https://doi.org/10.1111/j.1475$\underline{6765.2008 .00775 . x}$

Barbieri, P. (2009). Flexible Employment and Inequality in Europe. European Sociological Review, 25(6), 621-628. https://doi.org/10.1093/esr/jcp020

Barbieri, P. (2011). Italy: No Country for Young Men (and Women): The Italian Way of Coping with Increasing Demands for Labour Market Flexibility and Rising Welfare Problems. In H.-P. Blossfeld, S. Buchholz, D. Hofäcker, \& K. Kolb (Eds.), Globalized Labour Markets and Social Inequality in Europe (pp. 108-145). Palgrave Macmillan UK. https://doi.org/10.1057/9780230319882 5

Bassoli, M., Monticelli, L., Pincella, C., (2011). Valori, partecipazione e produzione culturale nei circoli giovanili ARCI: una ricerca comparativa nella provincia di Mantova, Milano: FrancoAngeli

Bassoli, M. \& Monticelli, L. (2016). Precarious Voices? Types of "Political Citizens" and Repertoires of Action among European Youth. PArtecipazione e COnflitto 9(3), 824-856.

Bassoli, M., (2017). Catholic Versus Communist: An Ongoing Issue-The Role of Organizational Affiliation in Accessing the Policy Arena. VOLUNTAS: International Journal of Voluntary and Nonprofit Organizations 28, 1135-1156. https://doi.org/10.1007/s11266-016-9708-1

Bay, A.-H., \& Blekesaune, M. (2002). Youth, unemployment and political marginalisation. International Journal of Social Welfare, 11(2), 132-139. https://doi.org/10.1111/1468-2397.00207

Brady, H. E., Verba, S., \& Schlozman, K. L. (1995). Beyond Ses: A Resource Model of Political Participation. The American Political Science Review, 89(2), 271-294. https://doi.org/10.2307/2082425

Bruno, G. S. F., Caroleo, F. E., \& Dessy, O. (2014). Temporary Contracts and Young Workers' Job Satisfaction in Italy. In M. Á. Malo \& D. Sciulli (Eds.), Disadvantaged Workers (pp. 95-120). Cham: Springer International Publishing. https://doi.org/10.1007/978-3-319-04376-0_6

Castañeda, E. (2012). The Indignados of Spain: A Precedent to Occupy Wall Street. Social Movement Studies, 11(3-4), 309-319. https://doi.org/10.1080/14742837.2012.708830 
Coffé, H., \& Bolzendahl, C. (2010). Same Game, Different Rules? Gender Differences in Political Participation. Sex Roles, 62(5-6), 318-333. https://doi.org/10.1007/s11199-009-9729-y

Corbetta, P., \& Colloca, P. (2013). Job precariousness and political orientations: The case of Italy. South European Society and Politics, 18(3), 333-354. http://dx.doi.org/10.1080/13608746.2013.769791

Della Porta, D., Silvasti, T., Hänninen, S., \& Siisiäinen, M. (Eds.). (2016). The new social division: Making and unmaking precariousness. Basingstoke: Palgrave Macmillan.

De Witte, H. and Näswall, K. (2003). ‘'Objective’ vs `Subjective' Job Insecurity: Consequences of Temporary Work for Job Satisfaction and Organizational Commitment in Four European Countries', Economic and Industrial Democracy, 24(2), pp. 149-188. doi: 10.1177/0143831X03024002002.

Demazière, D., \& Pignoni, M. T. (1998). Chômeurs--du silence à la révolte : sociologie d'une action collective. Paris: Hachette littératures.

Diamanti, I. (2009). Mappe dell'Italia politica: bianco, rosso, verde, azzurro--e tricolore. Bologna: Il mulino.

Doerr, N., Mattoni, A., \& Teune, S. (2015). Visuals in Social Movements. In D. Della Porta \& M. Diani (Eds.), The Oxford Handbook of Social Movements. Oxford University Press. https://doi.org/10.1093/oxfordhb/9780199678402.013.48

Driskell, R., Embry, E., \& Lyon, L. (2008). Faith and Politics: The Influence of Religious Beliefs on Political Participation. Social Science Quarterly, 89(2), 294-314. https://doi.org/10.1111/j.1540-6237.2008.00533.x

Emmenegger, P., Marx, P., \& Schraff, D. (2015). Labour market disadvantage, political orientations and voting: how adverse labour market experiences translate into electoral behaviour. Socio-Economic Review, 13(2), 189-213. https://doi.org/10.1093/ser/mwv003

Eggert, N., \& Giugni, M. (2010). Does Associational Involvement Spur Political Integration? Political Interest and Participation of Three Immigrant Groups in Zurich. Swiss Political Science Review, 16(2), 175-210. https://doi.org/10.1002/j.1662-6370.2010.tb00157.x

Eichhorst, W., \& Marx, P. (Eds.). (2015). Non-standard employment in post-industrial labour markets: an occupational perspective. Cheltenham: Edward Elgar Publishing.

Forno, F., \& Graziano, P. R. (2014). Sustainable community movement organisations. Journal of Consumer Culture, 14(2), 139-157. https://doi.org/10.1177/1469540514526225

Gamson, W. A. (1968). Stable unrepresentation in American society. American Behavioral Scientist, 12(2), 15-21.

Gebel, M., \& Giesecke, J. (2011). Labor market flexibility and inequality: the changing skill-based temporary employment and unemployment risks in Europe. Social Forces, 90(1), 17-39. https://doi.org/10.1093/sf/90.1.17

Giugni, M. (2010). The contentious politics of unemployment in Europe: Welfare states and political opportunities. Basingstoke: Palgrave Macmillan.

Harvey, G., Rhodes, C., Vachhani, S. J., \& Williams, K. (2016). Neo-villeiny and the service sector: the case of hyper flexible and precarious work in fitness centres. Work, Employment and Society, 31(1), 19-35. https://doi.org/10.1177/0950017016638023

Hirschman, A. O. (1970). Exit, voice, and loyalty; responses to decline in firms, organizations, and states. Cambridge, Mass: Harvard University Press.

Jessoula, M., Graziano, P. R., \& Madama, I. (2010). 'Selective Flexicurity' in Segmented Labour Markets: The Case of Italian 'Mid-Siders'. Journal of Social Policy, 39(04), 561-583. https://doi.org/10.1017/S0047279410000498

Kern, A., Marien, S., \& Hooghe, M. (2015). Economic Crisis and Levels of Political Participation in Europe (20022010): The Role of Resources and Grievances. West European Politics, 38(3), $465-490$. https://doi.org/10.1080/01402382.2014.993152

Keune, M. (2015). Trade unions, precarious work and dualisation in Europe. In W. Eichhorst \& P. Marx (Eds.), NonStandard Employment in Post-Industrial Labour Markets (pp. 378-400). Edward Elgar Publishing. https://doi.org/10.4337/9781781001721.00021 
Kriesi, H., Grande, E., Lachat, R., Dolezal, M., Bornschier, S., \& Frey, T. (2006). Globalization and the transformation of the national political space: Six European countries compared. European Journal of Political Research, 45(6), 921-956. https://doi.org/10.1111/j.1475-6765.2006.00644.X

Kriesi, H. (2010). Restructuration of partisan politics and the emergence of a new cleavage based on values. West European Politics, 33(3), 673-685. http://dx.doi.org/10.1080/01402381003654726

La Due Lake, R., \& Huckfeldt, R. (1998). Social Capital, Social Networks, and Political Participation. Political Psychology, 19(3), 567-584. https://doi.org/10.1111/0162-895X.00118

Lahusen, C. (2013). The Protests of the Unemployed in France, Germany and Sweden (1994-2004): Protest Dynamics and Political Contexts. Social Movement Studies, 12(1), 1-22. https://doi.org/10.1080/14742837.2012.723369

Lazarsfeld, P. F., Jahoda, M., \& Zeisel, H. (1981). Les chômeurs de Marienthal. Paris: Éditions de Minuit.

Lima, M. d. P. C., \& Artiles, A. M. (2013). Youth voice(s) in EU countries and social movements in southern Europe. Transfer: European Review of Labour and Research, 19(3), 345-364. https://doi.org/10.1177/1024258913493732

Lodovici, M. S., \& Semenza, R. (Eds.). (2012). Precarious work and high-skilled youth in Europe (Vol. 937). Milan: FrancoAngeli.

Lorenzini, J., \& Giugni, M. (2012). Employment Status, Social Capital, and Political Participation: A Comparison of Unemployed and Employed Youth in Geneva. Swiss Political Science Review, 18(3), 332-351. https://doi.org/10.1111/j.1662-6370.2012.02076.x

Lorenzini, J., Bassoli, M., (2015). Gender ideology: The last barrier to womens participation in political consumerism? International Journal of Comparative Sociology 56, 460-483. https://doi.org/10.1177/0020715215625726

Malin, B. J., \& Chandler, C. (2016). Free to Work Anxiously: Splintering Precariousness Among Drivers for Uber and Lyft. Communication, Culture \& Critique, n/a-n/a. https://doi.org/10.1111/cccr.12157

Marien, S., Hooghe, M., \& Quintelier, E. (2010). Inequalities in Non-institutionalised Forms of Political Participation: A Multi-level Analysis of 25 countries. Political Studies, 58(1), 187-213. https://doi.org/10.1111/j.14679248.2009.00801.x

Marx, P., \& Picot, G. (2013). The party preferences of atypical workers in Germany. Journal of European Social Policy, 23(2), 164-178. https://doi.org/10.1177/0958928712471222

Marx, P. (2014). The insider-outsider divide and economic voting: Testing a new theory with German electoral data. Socio-Economic Review, 14(1), 97-118. https://doi.org/10.1093/ser/mwu022

Mattoni, A., \& Doerr, N. (2007). Images within the precarity movement in Italy. Feminist Review, 87(1), $130-135$. https://doi.org/10.1057/palgrave.fr.9400356

Mattoni, A., \& Vogiatzoglou, M. (2014). Italy and Greece, before and after the crisis: between mobilization and resistance against precarity. Quaderni, (2), 57-71.

Mattoni, A. (2016). Media practices and protest politics: how precarious workers mobilise. London; New York: Routledge. Retrieved from http://www.tandfebooks.com/isbn/9781315594521

Maurer, S., \& Mayer, N. (2001). Les chômeurs en action, (décembre 1997-mars 1998) mobilisation collective et ressources compensatoires. Paris; Montréal; Budapest: 1'Harmattan.

McFarland, D. A., \& Thomas, R. J. (2006). Bowling Young: How Youth Voluntary Associations Influence Adult Political Participation. American Sociological Review, $41(3), \quad 425$. https://doi.org/10.1177/000312240607100303

Micheletti, M. (2003). Political Virtue and Shopping: Individuals. Consumerism and Collective Action. Basingstoke: Palgrave Macmillan.

Milkman, R., \& Ott, E. (Eds.). (2014). New labor in New York: precarious workers and the future of the labor movement. Ithaca: ILR Press, an imprint of Cornell University Press. 
Monticelli, L., Baglioni, S. \& Bassoli, M. (2016). In A World that Does Not Belong to Me. Recounting Unemployment Experiences of Italian Youth In Times of Crisis. In Lahusen, C. \& Giugni, M. (Eds.) Experiencing Long-Term Unemployment in Europe. Youth on the Edge. Basingstoke: Palgrave Macmillan.

Monticelli, L., \& Bassoli, M. (2017). What About the Welfare State? Exploring Precarious Youth Political Participation in the Age of Grievances. Acta Politica (Online first).

https://doi.org/10.1057/s41269-017-0047-z

Murgia, A., \& Armano, E. (Eds.). (2012). Mappe della precarieta. Spazi, rappresentazioni, esperienze e critica delle politiche del lavoro che cambia. Bologna: I libri di Emil.

OECD (2011). Oecd Employment Outlook 2011. Paris: Oecd publishing. Retrieved from http://site.ebrary.com/id/10509885

Ogris, G., \& Westphal, S. (2005). Political Participation of Young People in Europe - Development of Indicators for Comparative Research in the European Union, deliverable to the European Commission. Retrieved 18 February 2012, from http://www.sora.at/fileadmin/images/content/Pages/euyoupart ergebnisse finalcomparativereport.pdf

Pavlopoulos, D. (2013). Starting Your Career With a Fixed-Term Job: Stepping-Stone or 'Dead End'? Review of Social Economy, 71(4), 474-501. https://doi.org/10.1080/00346764.2013.799970

Picchio, M. (2012). The Dynamics of Unemployment, Temporary and Permanent Employment in Italy. In T. Addabbo \& G. Solinas (Eds.), Non-Standard Employment and Quality of Work (pp. 127-147). Physica-Verlag HD. https://doi.org/10.1007/978-3-7908-2106-2_7

Piven, F. F., \& Cloward, R. A. (1977). Poor people's movements : why they succeed, how they fail. New York: Pantheon Books.

Pizzorno, A. (1966). Introduzione allo studio della partecipazione politica. Quaderni Di Sociologia, 15(3/4), 235-287.

Polavieja, J. G. (1999). How do labour market experiences affect political attitudes? Analysing the political effects of labour market dualisation in Spain. Estudio Working Paper, Madrid: Juan March Institute of Study and Research (142).

Putnam, R., (2000). Bowling alone: The collapse and revival of American community. New York, NY,

Simon and Schuster.

Lodovici, M., \& Semenza, R. (Eds.). (2012). Precarious work and high-skilled youth in Europe. Milano, Italy: FrancoAngeli.

Scherer, S. (2001). Early Career Patterns: A Comparison of Great Britain and West Germany. European Sociological Review, 17(2), 119-144. https://doi.org/10.1093/esr/17.2.119

Scherer, S. (2004). Stepping-Stones or Traps?: The Consequences of Labour Market Entry Positions on Future Careers in West Germany, Great Britain and Italy. Work, Employment \& Society, 18(2), 369-394. https://doi.org/10.1177/09500172004042774

Schlozman, K. L., Burns, N., \& Verba, S. (1994). Gender and the Pathways to Participation: The Role of Resources. The Journal of Politics, 56(04), 963-990. https://doi.org/10.2307/2132069

Schlozman, K. L., Burns, N., \& Verba, S. (1999). 'What Happened at Work Today?': A Multistage Model of Gender, Employment, and Political Participation. The Journal of Politics, 61(01), 29-53. https://doi.org/10.2307/2647774

Schur, L. (2003). Employment and the Creation of an Active Citizenry. British Journal of Industrial Relations, 41(4), 751-771. https://doi.org/10.1046/j.1467-8543.2003.00297.x

Solt, F. (2008). Economic Inequality and Democratic Political Engagement. American Journal of Political Science, 52(1), 48-60. https://doi.org/10.1111/j.1540-5907.2007.00298.x

Stolle, D., \& Hooghe, M. (2011). Shifting Inequalities: Patterns of exclusion and inclusion in emerging forms of political participation. European Societies, 13(1), 119-142. https://doi.org/10.1080/14616696.2010.523476 
Stolle, D., Hooghe, M., \& Micheletti, M. (2005). Politics in the Supermarket: Political Consumerism as a Form of Political Participation. International Political Science Review/ Revue Internationale de Science Politique, 26(3), 245-269. https://doi.org/10.1177/0192512105053784

Tarrow, S. (2013). Contentious Politics. In The Wiley-Blackwell Encyclopedia of Social and Political Movements. Blackwell Publishing Ltd. https://doi.org/10.1002/9780470674871.wbespm051

Teorell, J., Torcal, M., \& Montero, J. R. (2007). Political Participation: Mapping the Terrain. In J. W. van Deth, J. R. Montero, \& A. Westholm (Eds.), Citizenship and Involvement in European Democracies: A Comparative Analysis (pp. 334-357). London: Routledge.

Van Der Meer, T. W. G. (Tom), \& Van Ingen, E. J. (Erik). (2009). Schools of democracy? Disentangling the relationship between civic participation and political action in 17 European countries. European Journal of Political Research, 48(2), 281-308. https://doi.org/10.1111/j.1475-6765.2008.00836.x

Van Der Meer, T. W. G., van Deth, J. W., \& Scheepers, P. L. H. (2009). The Politicized Participant: Ideology and Political Action in 20 Democracies. Comparative Political Studies, 42(11), $1426-1457$. https://doi.org/10.1177/0010414009332136

Verba, S., Nie, H. N., \& Kim, J.-O. (1978). Participation and political equality : a seven-nation comparison. Cambridge: Cambridge University Press.

Verba, S., Schlozman, K. L., Brady, H., \& Nie, N. H. (1993). Citizen Activity: Who Participates? What Do They Say? The American Political Science Review, 87(2), 303. https://doi.org/10.2307/2939042

Webster, J. (2016). Microworkers of the Gig Economy: Separate and Precarious. New Labor Forum, 25(3), 56-64. https://doi.org/10.1177/1095796016661511

Wilkes, R. (2004). First nation politics: deprivation, resources, and participation in collective action. Sociological Inquiry, 74(4), 570-589. https://doi.org/ 10.1111/j.1475-682X.2004.00105 
APPENDIX 1

CONFIRMATORY FACTOR ANALYSIS (OBLIMIN) ON SELECTED ITEMS OF POLITICAL PARTICIPATION

\begin{tabular}{lccccr}
\hline & Factor 1 & Factor 2 & Facto 3 & Factor 4 & Uniqueness \\
\hline $\begin{array}{l}\text { Voting national } \\
\text { election }\end{array}$ & $\mathbf{0 . 8 0 8 3}$ & 0.0194 & -0.0060 & 0.0314 & 0.3463 \\
\hline Voting local election & $\mathbf{0 . 8 0 9 7}$ & -0.0199 & 0.0053 & -0.0233 & 0.3434 \\
\hline Work in a party & 0.0299 & -0.0314 & -0.0405 & $\mathbf{0 . 4 8 6 1}$ & 0.7763 \\
\hline Work in action group & -0.0147 & 0.0773 & 0.0364 & $\mathbf{0 . 4 8 6 5}$ & 0.7280 \\
\hline Sign a petition & 0.0449 & $\mathbf{0 . 3 2 3 2}$ & 0.1704 & 0.0008 & 0.8155 \\
\hline Demonstration & 0.0272 & 0.0234 & $\mathbf{0 . 6 5 1 2}$ & -0.0432 & 0.5661 \\
\hline Boycotting & 0.0111 & $\mathbf{0 . 5 0 5 3}$ & -0.0364 & -0.0720 & 0.7683 \\
\hline Buycotting & -0.0157 & $\mathbf{0 . 6 3 9 1}$ & -0.0100 & -0.0092 & 0.6012 \\
\hline Donate money & 0.0033 & $\mathbf{0 . 3 8 1 0}$ & 0.0062 & 0.0998 & 0.8237 \\
\hline Strike & -0.0322 & -0.0136 & $\mathbf{0 . 6 6 2 9}$ & 0.0332 & 0.5634 \\
\hline Party membership & -0.0420 & 0.2149 & 0.0135 & 0.1231 & 0.9223 \\
\hline Cronbach's alpha & 0.8430 & 0.4640 & 0.7209 & 0.6867 & \\
\hline
\end{tabular}

Note: Extraction method: Principal component analysis

Rotation method: Promax with Kaiser's normalization

Items were selected from the following question 'In the following, we name some political activities. For each of them could you please tell me if you have done it during the last 12 months?'. Listed items were: Worked in a political party; Worked in a political action group; Signed a petition; Taken part in a public demonstration; Boycotted certain products; Deliberately bought certain products for political reasons; Donated money to a political organization or group; Taken part in a strike. Together with these 10 items, we added a further one concerning membership in political parties. 


\section{APPENDIX 2}

\section{INDEPENDENT VARIABLES OPERATIONALISATION}

Age is a continuous variable ranging from 18 to 34 years old, and nationality is a dichotomous variable coded as one when the respondent holds Italian citizenship. Education is a categorical variable coded as zero for those having achieved below secondary education, one for those with a secondary education, and two for those with a tertiary education. As for social capital, we took into consideration both existing conceptualisation-by measuring the number of friends (none, less than two friends or more than two) - and civic engagement-union membership and civil society membership, coded as one for members (past and present) and zero for youth who have never been members. Financial resources are taken into account with a proxy. Financial difficulties are measured with a dichotomous variable based on a question asking how difficult it is to cope with one's current income. Financial difficulty is coded as one when the respondent finds it difficult to cope with current income and zero otherwise. Regarding time availability, we took into account the amount of time spent at home looking after relatives. Finally a set of eight items captures the political dimension. Political interest is measured by asking whether the respondent is interested in politics (four-point scale, dichotomized). Internal political efficacy is measured through a question asking whether persons like themselves have an influence on politics (agreement with the sentence using a four-point scale, dichotomized). Political cynicism is based on a question asking whether political parties are only interested in the respondent's vote (agreement with the sentence using a four-point scale, dichotomized). Political understanding is measured through a question asking 'There are times in which politics is so complicated that people like me don't understand what's going (agreement with the sentence using a four-point scale, dichotomized). Political trust measures if the respondent had any trust in the political system, considering six institutions: three government tiers (national, regional or local level) and both the legislative assembly and the government. Therefore an elevenpoint scale was dichotomized, scoring one for those holding a trust level higher than six and zero otherwise, for each institution. The final score was a dummy valuing one if the respondent trusted at least one institution out of six, zero otherwise. The political dimension is completed by a measure of participants' satisfaction with Italian democracy (ten-point scale, dichotomized). 
APPENDIX 3

SUMMARY STATISTICS FOR CONTROL AND EXPLANATORY VARIABLES

\begin{tabular}{|c|c|c|c|c|c|c|c|c|}
\hline & \multicolumn{4}{|c|}{ Regular workers } & \multicolumn{4}{|c|}{ Precarious workers } \\
\hline & mean & $\mathrm{sd}$ & $\min$ & $\max$ & mean & sd & $\min$ & $\max$ \\
\hline Voting & 0.88 & 0.32 & 0 & 1 & 0.95 & 0.22 & 0 & 1 \\
\hline Party politics & 0.00 & 0.00 & 0 & 0 & 0.02 & 0.13 & 0 & 1 \\
\hline Consumerism & 0.18 & 0.38 & 0 & 1 & 0.24 & 0.43 & 0 & 1 \\
\hline Collective action & 0.34 & 0.47 & 0 & 1 & 0.34 & 0.48 & 0 & 1 \\
\hline Age & 24.14 & 3.38 & 18 & 34 & 23.29 & 2.98 & 18 & 34 \\
\hline Gender & 0.58 & 0.49 & 0 & 1 & 0.61 & 0.49 & 0 & 1 \\
\hline Education level & 2.07 & 0.63 & 1 & 3 & 2.07 & 0.58 & 1 & 3 \\
\hline Citizenship & 0.97 & 0.17 & 0 & 1 & 0.98 & 0.13 & 0 & 1 \\
\hline Living with Partner & 0.14 & 0.34 & 0 & 1 & 0.05 & 0.22 & 0 & 1 \\
\hline $\begin{array}{l}\text { Trade union } \\
\text { membership }\end{array}$ & 0.02 & 0.15 & 0 & 1 & 0.00 & 0.05 & 0 & 1 \\
\hline $\begin{array}{l}\text { Associational } \\
\text { membership }\end{array}$ & 0.05 & 0.22 & 0 & 1 & 0.07 & 0.25 & 0 & 1 \\
\hline Number of friends & 0.85 & 0.76 & 0 & 2 & 0.79 & 0.80 & 0 & 2 \\
\hline Financial difficulties & 0.17 & 0.37 & 0 & 1 & 0.18 & 0.38 & 0 & 1 \\
\hline $\begin{array}{l}\text { Caring of someone at } \\
\text { home }\end{array}$ & 0.03 & 0.18 & 0 & 1 & 0.03 & 0.17 & 0 & 1 \\
\hline Political interest & 0.26 & 0.44 & 0 & 1 & 0.46 & 0.50 & 0 & 1 \\
\hline $\begin{array}{l}\text { Internal political } \\
\text { efficacy }\end{array}$ & 0.17 & 0.37 & 0 & 1 & 0.20 & 0.40 & 0 & 1 \\
\hline Political cynicism & 0.84 & 0.36 & 0 & 1 & 0.84 & 0.37 & 0 & 1 \\
\hline Understands politics & 0.34 & 0.48 & 0 & 1 & 0.26 & 0.44 & 0 & 1 \\
\hline Trust & 0.73 & 0.44 & 0 & 1 & 0.82 & 0.38 & 0 & 1 \\
\hline $\begin{array}{l}\text { Satisfaction with } \\
\text { democracy }\end{array}$ & 0.49 & 0.50 & 0 & 1 & 0.48 & 0.50 & 0 & 1 \\
\hline $\begin{array}{l}\text { Extreme self- } \\
\text { positioning }\end{array}$ & 0.30 & 0.46 & 0 & 1 & 0.28 & 0.45 & 0 & 1 \\
\hline $\begin{array}{l}\text { Quadratic self- } \\
\text { positioning }\end{array}$ & 37.78 & 33.36 & 0 & 110 & 39.79 & 34.31 & 0 & 110 \\
\hline $\begin{array}{l}\text { Political self } \\
\text { positioning }\end{array}$ & 4.92 & 2.95 & 0 & 10 & 5.11 & 2.93 & 0 & 10 \\
\hline Observations & 296 & & & & 337 & & & \\
\hline
\end{tabular}

Note:

(+) Precarious occupational status includes the following types of contracts: fix-term contract, temporary contract, seasonal contract, on-call contract, 'on project' collaboration. Interviewees working with an open-ended contract have been labelled 'regular' workers and treated as a control group in the analysis. See full questionnaire for further details.

${ }^{(+)}$The list of civil society organizations used to build the dummy variable includes: religious organizations, cooperatives, social movement organizations, and other civil society organizations. See full questionnaire for further details.

${ }^{(*)}$ We derived 'Interest in politics' dummy from the question 'How interested would you say you are in politics?'. Possible answers ranged in a 4 point scale from $1=$ 'Not interested at all' to $4=$ 'Very interested' with intermediate positions being $2=$ 'Not very interested', $3=$ 'Fairly interested'. We collapsed modalities 3-4 into $1=$ 'medium-high interest' and answers 1-2 into $0=$ 'medium-low interest'.

${ }^{(* *)}$ We derived 'Internal political efficacy' dummy from the question 'People like me definitely have an influence on governmental politics'. Possible answers ranged in a 4 point scale from 1= 'Totally 
disagree' to $4=$ 'Totally agree 'with intermediate positions being $2=$ 'Disagree', $3=$ 'Agree. We collapsed modalities 3-4 into $1=$ 'Feeling efficacious' and answers 1-2 into $0=$ 'Feeling inefficacious' ${ }^{(* * *)}$ We derived 'Understand politics' dummy from the question 'Sometimes politics is so complicated that people like me do not understand anymore what is going on'. Possible answers ranged in a 4 point scale from $1=$ 'Totally disagree' to $4=$ 'Totally agree 'with intermediate positions being 2= 'Disagree', 3= 'Agree. We collapsed modalities 3-4 into 1= 'understanding' and answers $1-2$ into $0=$ 'no understanding'. 
APPENDIX 4

LOGISTIC REGRESSION MODEL ON VOTING

\begin{tabular}{|c|c|c|c|c|c|c|c|c|c|}
\hline \multirow{2}{*}{$\overline{\text { Precarious workers }}$} & \multirow{2}{*}{\begin{tabular}{|l|} 
Baseline model \\
$1.933^{*}(0.648)$
\end{tabular}} & \multicolumn{2}{|c|}{ Partial Model A } & \multicolumn{2}{|c|}{ Partial Model B } & \multicolumn{2}{|c|}{ Model 1} & \multicolumn{2}{|c|}{ Model 2} \\
\hline & & $1.966^{*}$ & $(0.661)$ & $1.913^{+}$ & $(0.644)$ & $1.949^{*}$ & $(0.658)$ & 1.395 & $(0.974)$ \\
\hline Age & $0.895^{+}(0.0558)$ & 0.901 & $(0.0571)$ & $0.895^{+}$ & $(0.0559)$ & $0.901^{+}$ & $(0.0572)$ & $0.897^{+}$ & $(0.0574)$ \\
\hline Gender & $1.759^{+}(0.593)$ & $1.798^{+}$ & $(0.608)$ & $1.767^{+}$ & $(0.596)$ & $1.805^{+}$ & $(0.610)$ & $1.818^{+}$ & $(0.615)$ \\
\hline \multicolumn{10}{|c|}{ Education (ref. Lower secondary) } \\
\hline Secondary & $1.065(0.453)$ & 1.030 & $(0.441)$ & 1.079 & $(0.461)$ & 1.044 & $(0.448)$ & 1.035 & $(0.446)$ \\
\hline Tertiary & $1.273(0.659)$ & 1.281 & $(0.664)$ & 1.297 & $(0.675)$ & 1.304 & $(0.679)$ & 1.300 & $(0.679)$ \\
\hline Citizenship & (.) & 1 & (.) & 1 & (.) & 1 & (.) & 1 & (.) \\
\hline Living with Partner & $0.880 \quad(0.542)$ & 0.848 & $(0.524)$ & 0.897 & $(0.555)$ & 0.864 & $(0.537)$ & 0.882 & $(0.549)$ \\
\hline \multirow{2}{*}{\multicolumn{10}{|c|}{$\begin{array}{l}\text { Trade union membership } \\
\text { Associational membership }\end{array}$}} \\
\hline & & & & & & & & & \\
\hline Number of close friends & $1.335(0.296)$ & 1.341 & $(0.299)$ & 1.330 & $(0.295)$ & 1.336 & $(0.298)$ & 1.338 & $(0.298)$ \\
\hline Financial difficulties & $0.559(0.217)$ & 0.545 & $(0.213)$ & 0.566 & $(0.221)$ & 0.552 & $(0.217)$ & 0.546 & $(0.215)$ \\
\hline $\begin{array}{l}\text { Caring of someone at } \\
\text { home }\end{array}$ & $0.252^{*}(0.174)$ & $0.240^{*}$ & $(0.167)$ & $0.246^{*}$ & $(0.171)$ & $0.235^{*}$ & $(0.164)$ & $0.245^{*}$ & $(0.172)$ \\
\hline Political interest & $4.427^{* *}(2.121)$ & $4.312^{* *}$ & $(2.068)$ & $4.507^{* *}$ & (2.174) & $4.375^{* *}$ & $(2.110)$ & $4.422^{* *}$ & $(2.137)$ \\
\hline $\begin{array}{l}\text { Internal political } \\
\text { efficacy }\end{array}$ & $0.380^{*}(0.153)$ & $0.387^{*}$ & $(0.157)$ & $0.383^{*}$ & $(0.155)$ & $0.390^{*}$ & $(0.158)$ & $0.383^{*}$ & $(0.156)$ \\
\hline Political cynicism & $0.459(0.269)$ & 0.457 & $(0.268)$ & 0.454 & $(0.266)$ & 0.452 & $(0.265)$ & 0.455 & $(0.266)$ \\
\hline Understands politics & $0.808 \quad(0.275)$ & 0.819 & $(0.280)$ & 0.811 & $(0.276)$ & 0.822 & $(0.281)$ & 0.831 & $(0.284)$ \\
\hline Trust & $1.701(0.611)$ & 1.701 & $(0.611)$ & 1.705 & $(0.612)$ & 1.704 & $(0.613)$ & 1.712 & $(0.616)$ \\
\hline $\begin{array}{l}\text { Satisfaction with } \\
\text { democracy }\end{array}$ & $0.773 \quad(0.259)$ & 0.774 & $(0.261)$ & 0.756 & $(0.259)$ & 0.759 & $(0.261)$ & 0.757 & $(0.260)$ \\
\hline $\begin{array}{l}\text { Extreme self- } \\
\text { positioning }\end{array}$ & & 1.303 & $(0.479)$ & & & 1.298 & $(0.477)$ & 1.269 & $(0.469)$ \\
\hline Political self-positioning & & & & 1.018 & $(0.0561)$ & 1.017 & $(0.0583)$ & 0.996 & $(0.0689)$ \\
\hline \multicolumn{10}{|l|}{ Interaction Precarious } \\
\hline Political self-positioning & & & & & & & & 1.066 & $(0.127)$ \\
\hline $\begin{array}{l}\text { chi2 (df_m) } \\
\mathrm{N}\end{array}$ & $\begin{array}{c}44.22(15)^{* * *} \\
564\end{array}$ & $\begin{array}{c}44.75 \\
564\end{array}$ & $(16)^{* * *}$ & $\begin{array}{c}44.33 \\
564\end{array}$ & $(16)^{* * *}$ & $\begin{array}{c}44.84 \\
564\end{array}$ & $(17)^{* * *}$ & $\begin{array}{c}45.13 \\
564\end{array}$ & $(18)^{* * *}$ \\
\hline$\overline{\text { aic }}$ & 325.5 & 327.0 & & 327.4 & & 328.9 & & 330.6 & \\
\hline bic & 394.9 & 400.7 & & 401.1 & & 406.9 & & 413.0 & \\
\hline
\end{tabular}

Exponentiated coefficients; Standard errors in parentheses

${ }^{+} p<0.10,{ }^{*} p<0.05,{ }^{* *} p<0.01,{ }^{* * *} p<0.001$ 
LOGISTIC REGRESSION MODEL ON CONSUMERISM

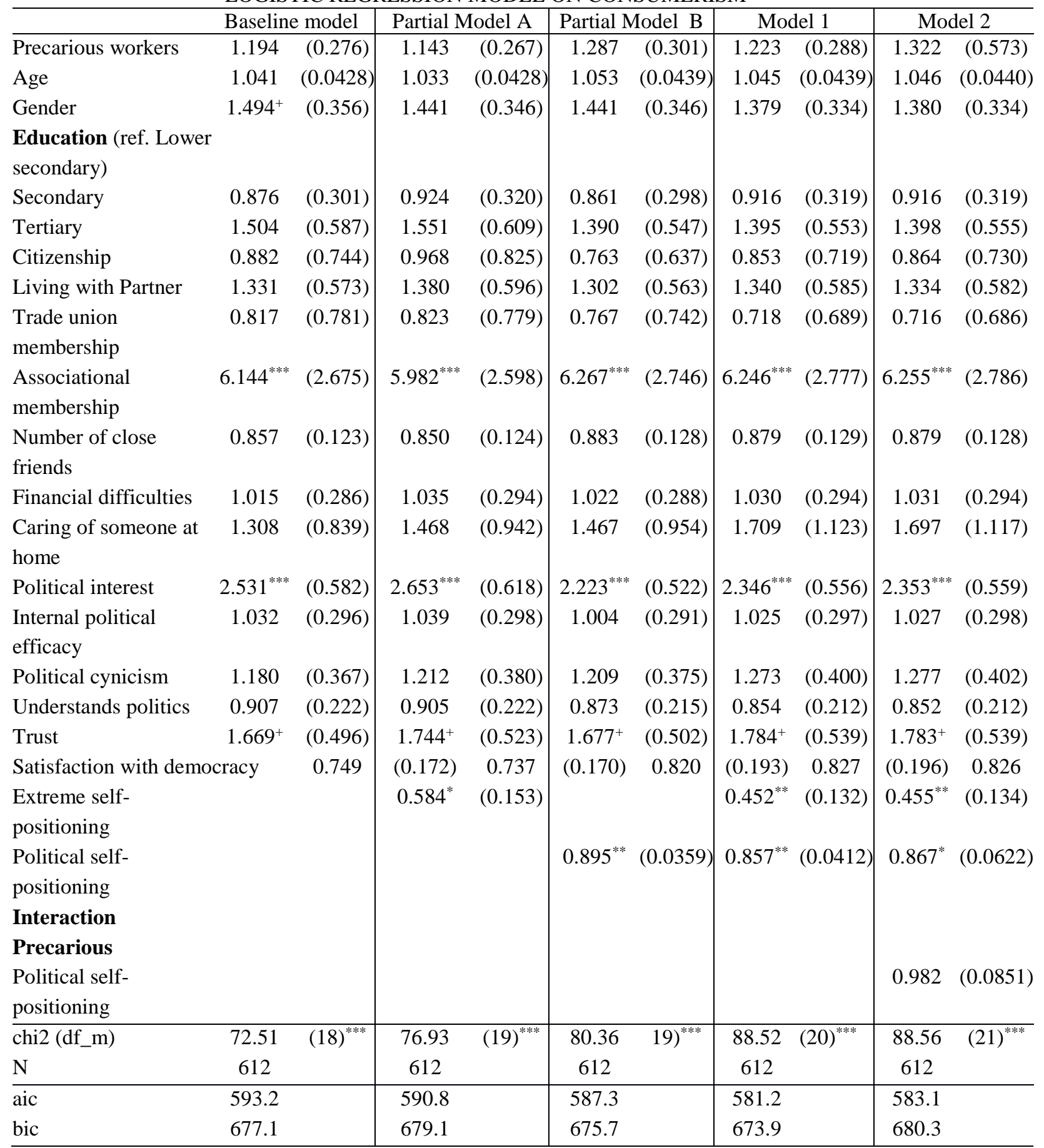

Exponentiated coefficients; Standard errors in parentheses

${ }^{+} p<0.10,{ }^{*} p<0.05,{ }^{* *} p<0.01,{ }^{* * *} p<0.001$ 


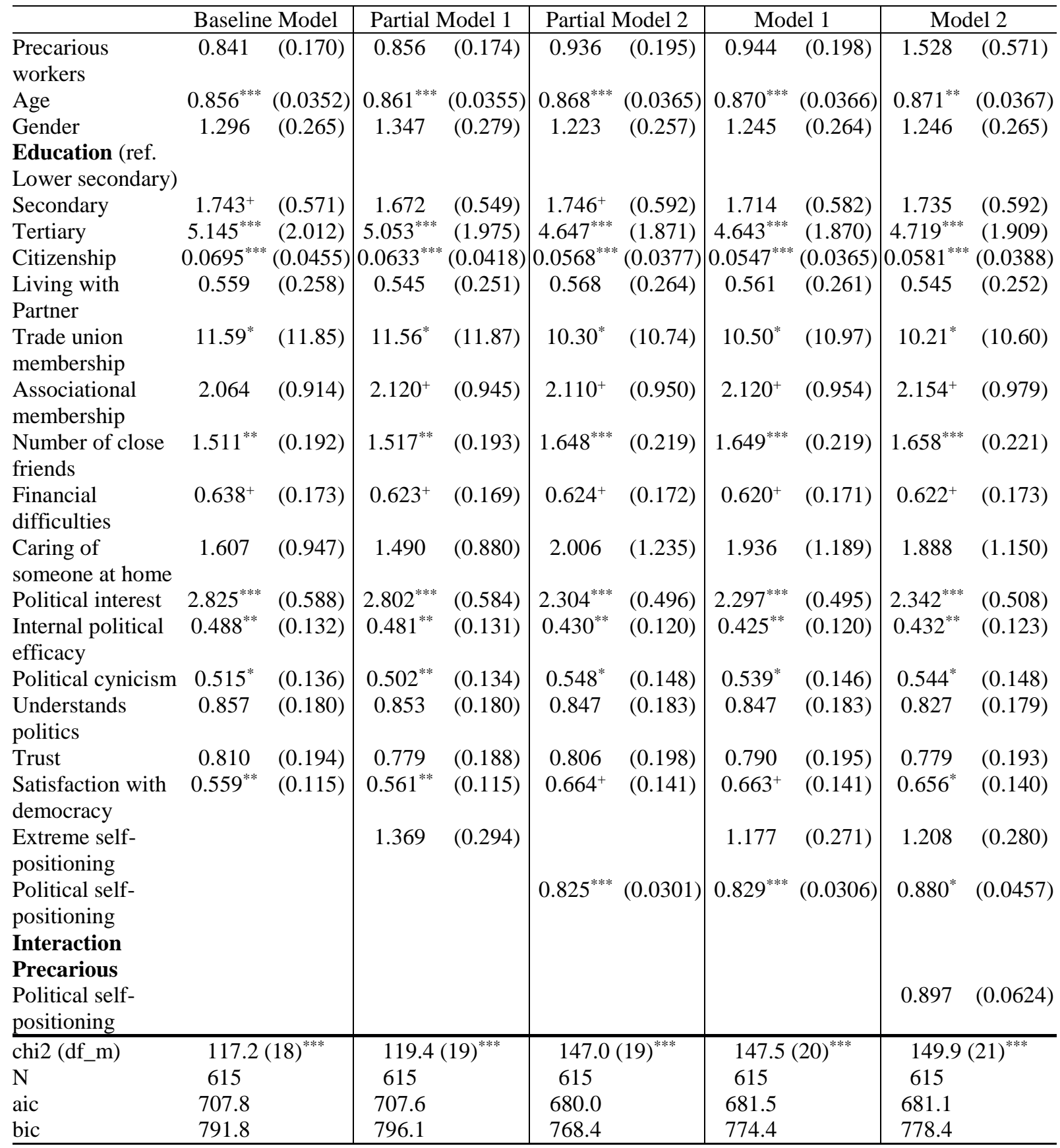

Exponentiated coefficients; Standard errors in parentheses ${ }^{+} p<0.10,{ }^{*} p<0.05,{ }^{* *} p<0.01,{ }^{* * *} p<0.001$ 


\section{APPENDIX 5}

ROBUSTNESS TEST FOR THE CURVILINEAR HYPOTHESIS, QUADRATIC TERM

\begin{tabular}{|c|c|c|c|c|c|c|c|c|}
\hline \multirow{2}{*}{ Precarious workers } & \multicolumn{2}{|c|}{ Voting 1} & \multicolumn{2}{|c|}{ Voting 2} & \multicolumn{2}{|c|}{ Consumerism 1} & \multicolumn{2}{|c|}{ Consumerism 2} \\
\hline & $1.899^{+}$ & $(0.640)$ & 1.297 & $(0.862)$ & 1.249 & $(0.293)$ & 1.389 & $(0.591)$ \\
\hline Age & $0.891^{+}$ & $(0.0564)$ & $0.887^{+}$ & $(0.0567)$ & 1.045 & $(0.0439)$ & 1.045 & $(0.0440)$ \\
\hline Gender & $1.751^{+}$ & $(0.593)$ & $1.768^{+}$ & $(0.599)$ & 1.401 & $(0.338)$ & 1.402 & $(0.338)$ \\
\hline \multicolumn{9}{|l|}{$\begin{array}{l}\text { Education (ref. Lower } \\
\text { secondary) }\end{array}$} \\
\hline Secondary & 1.097 & $(0.471)$ & 1.084 & $(0.467)$ & 0.878 & $(0.305)$ & 0.880 & $(0.306)$ \\
\hline Tertiary & 1.296 & $(0.675)$ & 1.292 & $(0.674)$ & 1.381 & $(0.546)$ & 1.386 & $(0.548)$ \\
\hline Citizenship & & & & & 0.862 & $(0.725)$ & 0.876 & $(0.739)$ \\
\hline Living with Partner & 0.913 & $(0.568)$ & 0.937 & $(0.584)$ & 1.327 & $(0.579)$ & 1.319 & $(0.575)$ \\
\hline Trade union membership & & & & & 0.741 & $(0.711)$ & 0.738 & $(0.707)$ \\
\hline Associational membership & & & & & $6.250^{* * * *}$ & $(2.755)$ & $6.261^{* * *}$ & $(2.765)$ \\
\hline Number of friends & 0.570 & $(0.223)$ & 0.562 & $(0.220)$ & 1.023 & $(0.290)$ & 1.025 & $(0.291)$ \\
\hline Financial difficulties & 1.324 & $(0.294)$ & 1.324 & $(0.294)$ & 0.867 & $(0.126)$ & 0.867 & $(0.126)$ \\
\hline Caring of someone at home & $0.254^{*}$ & $(0.177)$ & $0.266^{+}$ & $(0.187)$ & 1.708 & $(1.120)$ & 1.690 & (1.109) \\
\hline Political interest & $4.568^{* *}$ & $(2.215)$ & $4.642^{* *}$ & $(2.257)$ & $2.318^{* * * *}$ & $(0.549)$ & $2.325^{* * *}$ & $(0.551)$ \\
\hline Internal political efficacy & $0.381^{*}$ & $(0.155)$ & $0.374^{*}$ & $(0.152)$ & 1.025 & $(0.297)$ & 1.028 & $(0.298)$ \\
\hline Political cynicism & 0.455 & $(0.267)$ & 0.458 & $(0.266)$ & 1.224 & $(0.383)$ & 1.230 & $(0.385)$ \\
\hline Understands politics & 0.805 & $(0.275)$ & 0.815 & $(0.278)$ & 0.858 & $(0.212)$ & 0.855 & $(0.212)$ \\
\hline Trust & 1.710 & $(0.615)$ & 1.723 & $(0.620)$ & $1.772^{+}$ & $(0.535)$ & $1.770^{+}$ & $(0.534)$ \\
\hline Satisfaction with democracy & 0.755 & $(0.258)$ & 0.752 & $(0.256)$ & 0.825 & $(0.195)$ & 0.823 & $(0.194)$ \\
\hline Political self positioning & 1.077 & $(0.188)$ & 1.063 & $(0.188)$ & 1.131 & $(0.142)$ & 1.144 & $(0.150)$ \\
\hline $\begin{array}{l}\text { Quadratic term of political } \\
\text { positioning }\end{array}$ & 0.994 & $(0.0162)$ & 0.993 & $(0.0162)$ & $0.975^{*}$ & $(0.0127)$ & $0.975^{+}$ & $(0.0128)$ \\
\hline \multicolumn{9}{|l|}{ Interaction Precarious } \\
\hline Political self positioning & & & 1.076 & $(0.120)$ & & & 0.975 & $(0.0822)$ \\
\hline$\overline{\text { chi2 (df_m) }}$ & 44.44 & $(17)^{* * * *}$ & 44.87 & $(18)^{* * *}$ & 84.43 & $(20)^{* * * *}$ & 84.52 & $(21)^{* * * *}$ \\
\hline $\mathrm{N}$ & 564 & & 564 & & 612 & & 612 & \\
\hline aic & 329.3 & & 330.9 & & 585.3 & & 587.2 & \\
\hline bic & 407.3 & & 413.2 & & 678.0 & & 684.4 & \\
\hline
\end{tabular}

Exponentiated coefficients; Standard errors in parentheses

${ }^{+} p<0.10,{ }^{*} p<0.05,{ }^{* *} p<0.01,{ }^{* * *} p<0.001$ 
Figure A1. Figure 1. Predicted probabilities of voting by political self-positioning (curvilinear relationship)

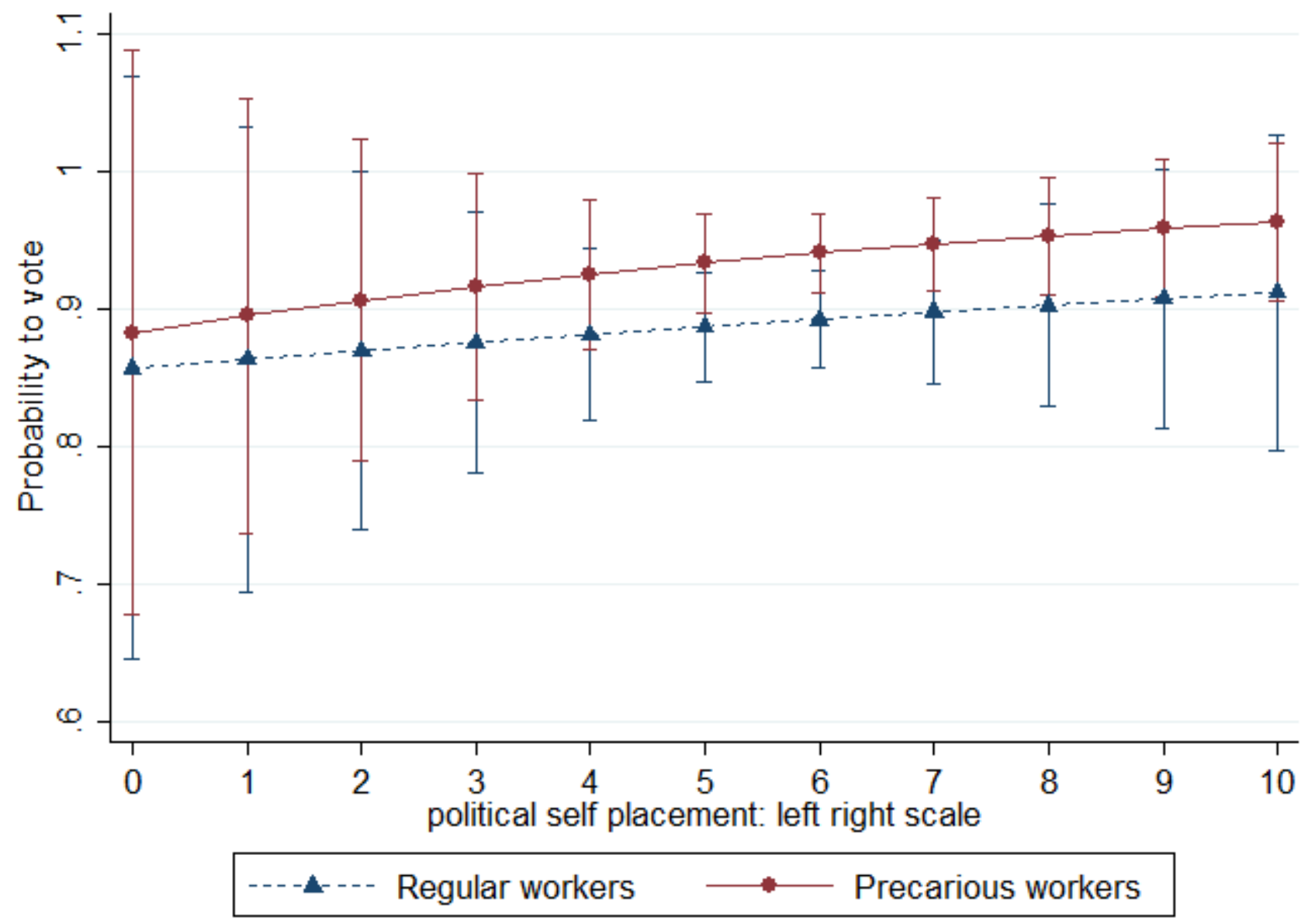

Source: AME are calculated based on annex 5, Model 2 (with all controls and interaction terms) 
Figure A2. Predicted probabilities of engaging in consumerism by political self-positioning (curvilinear relationship)

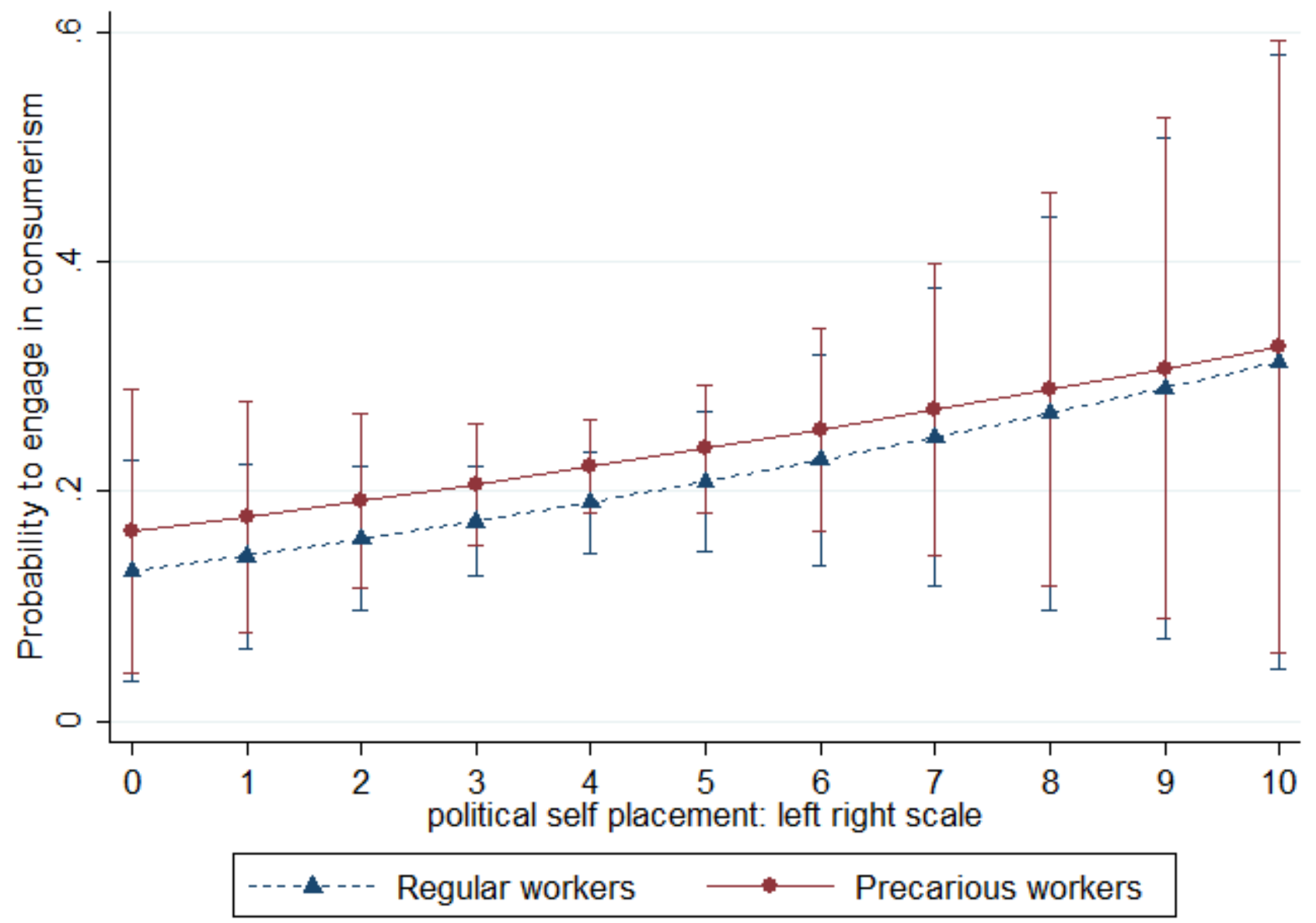

Source: AME are calculated based on annex 5, Model 2 (with all controls and interaction terms) 
Figure A3. Predicted probabilities of engaging in collective action by political self-positioning (curvilinear relationship)

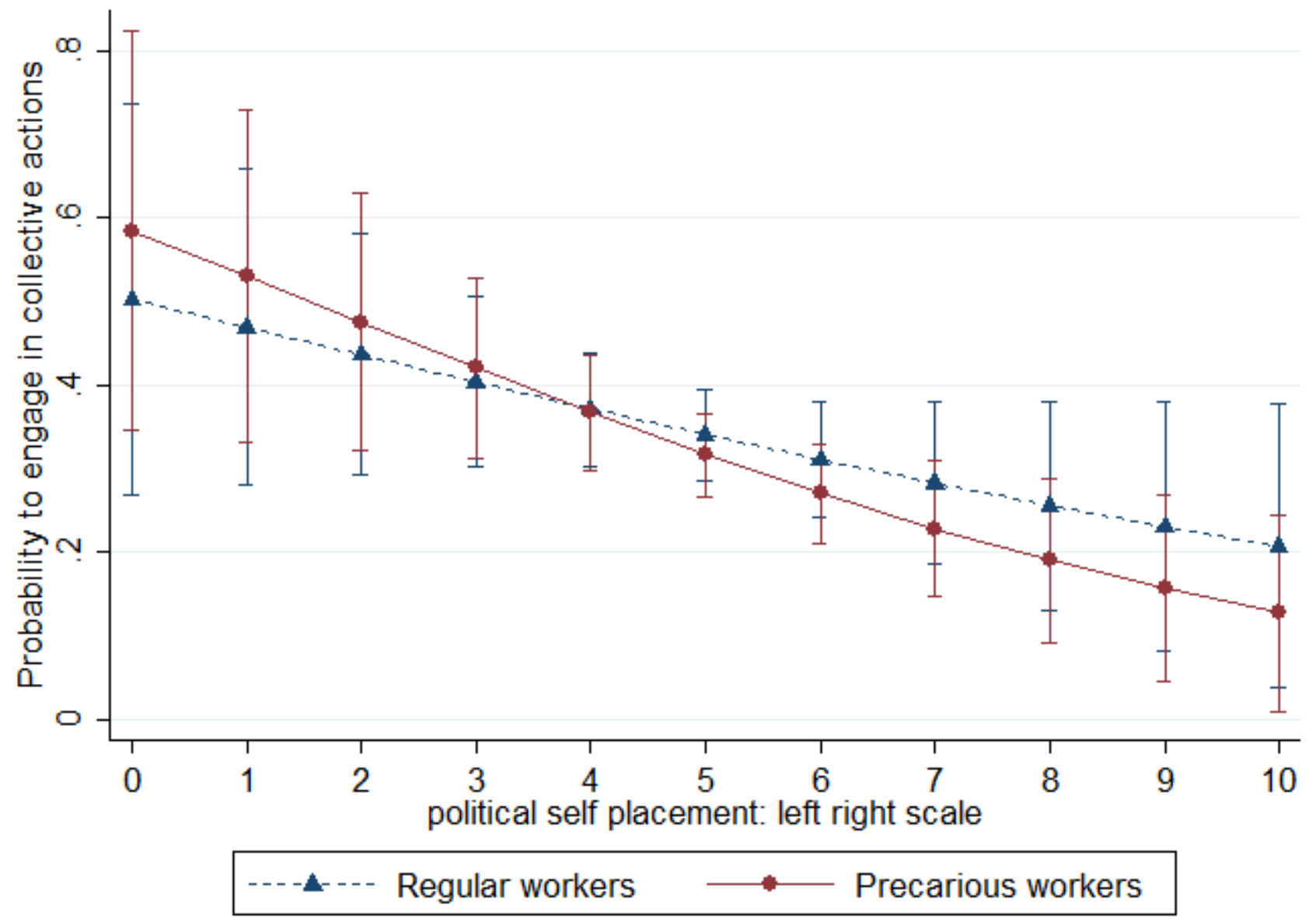

Source: AME are calculated based on annex 5, Model 2 (with all controls and interaction terms) 
APPENDIX 6

LOGISTIC REGRESSION MODEL

INTERACTION BETWEEN JOB STATUS AND EDUCATIONAL ATTAINMENTS

\begin{tabular}{|c|c|c|c|c|c|c|}
\hline \multirow{2}{*}{ Precarious workers } & \multicolumn{2}{|c|}{ Voting } & \multicolumn{2}{|c|}{ Consumerism } & \multicolumn{2}{|c|}{ Collective action } \\
\hline & 0.795 & $(0.602)$ & 0.822 & $(0.517)$ & 0.531 & $(0.337)$ \\
\hline Age & $0.895^{+}$ & $(0.0573)$ & 1.048 & $(0.0444)$ & $0.876^{* *}$ & $(0.0373)$ \\
\hline Gender & $1.782^{+}$ & $(0.603)$ & 1.350 & $(0.329)$ & 1.181 & $(0.253)$ \\
\hline $\begin{array}{l}\text { Education } \\
\text { (ref. Lower secondary) }\end{array}$ & & & & & & \\
\hline Secondary & 0.718 & $(0.394)$ & 0.637 & $(0.322)$ & 0.984 & $(0.459)$ \\
\hline Tertiary & 0.856 & $(0.555)$ & 1.290 & $(0.692)$ & $5.201^{* *}$ & $(2.697)$ \\
\hline Citizenship & & & 0.862 & $(0.729)$ & $0.0551^{* * *}$ & $(0.0368)$ \\
\hline Living with Partner & 0.905 & $(0.567)$ & 1.385 & $(0.608)$ & 0.606 & $(0.289)$ \\
\hline $\begin{array}{l}\text { Trade union } \\
\text { membership }\end{array}$ & & & 0.777 & $(0.751)$ & $11.60^{*}$ & $(12.27)$ \\
\hline $\begin{array}{l}\text { Associational } \\
\text { membership }\end{array}$ & & & $6.239^{* * *}$ & $(2.776)$ & $2.202^{+}$ & $(0.993)$ \\
\hline Number friends & 1.372 & $(0.307)$ & 0.886 & $(0.131)$ & $1.652^{* * *}$ & $(0.222)$ \\
\hline Financial difficulties & 0.572 & $(0.226)$ & 1.048 & $(0.301)$ & 0.652 & $(0.182)$ \\
\hline $\begin{array}{l}\text { Caring of someone at } \\
\text { home }\end{array}$ & $0.210^{*}$ & $(0.148)$ & 1.575 & $(1.040)$ & 1.761 & $(1.098)$ \\
\hline Political interest & $4.504^{* *}$ & $(2.180)$ & $2.324^{* * *}$ & $(0.555)$ & $2.253^{* * *}$ & $(0.490)$ \\
\hline $\begin{array}{l}\text { Internal political } \\
\text { efficacy }\end{array}$ & $0.378^{*}$ & $(0.154)$ & 1.033 & $(0.299)$ & $0.437^{* *}$ & $(0.123)$ \\
\hline Political cynicism & 0.446 & $(0.265)$ & 1.294 & $(0.407)$ & $0.560^{*}$ & $(0.154)$ \\
\hline Understands politics & 0.777 & $(0.269)$ & 0.838 & $(0.209)$ & 0.828 & $(0.181)$ \\
\hline Trust & 1.627 & $(0.592)$ & $1.755^{+}$ & $(0.532)$ & 0.766 & $(0.192)$ \\
\hline $\begin{array}{l}\text { Satisfaction with } \\
\text { democracy }\end{array}$ & 0.776 & $(0.267)$ & 0.838 & (0.199) & $0.670^{+}$ & $(0.144)$ \\
\hline $\begin{array}{l}\text { Extreme self } \\
\text { positioning }\end{array}$ & 1.273 & $(0.469)$ & $0.457^{* *}$ & $(0.134)$ & 1.219 & $(0.283)$ \\
\hline Self positioning & 1.016 & $(0.0583)$ & $0.856^{* *}$ & $(0.0412)$ & $0.825^{* * *}$ & $(0.0308)$ \\
\hline Inter: & & & & & & \\
\hline $\begin{array}{l}\text { Precarious workers X } \\
\text { Secondary }\end{array}$ & 2.874 & $(2.516)$ & 1.905 & $(1.322)$ & 2.840 & (1.934) \\
\hline $\begin{array}{l}\text { Precarious workers X } \\
\text { Tertiary }\end{array}$ & 3.418 & $(3.645)$ & 1.150 & $(0.859)$ & 0.763 & $(0.568)$ \\
\hline chi2 (df_m) & $46.52(19$ & & $89.98(22)^{* * *}$ & & $156.3(22)^{* * *}$ & \\
\hline $\mathrm{N}$ & 564 & & 612 & & 615 & \\
\hline aic & 331.2 & & 583.7 & & 676.7 & \\
\hline bic & 417.9 & & 685.3 & & 778.4 & \\
\hline
\end{tabular}

Exponentiated coefficients; Standard errors in parentheses

${ }^{+} p<0.10,{ }^{*} p<0.05,{ }^{* *} p<0.01,{ }^{* * *} p<0.001$ 